\title{
Ploughzone sampling in Denmark: isolating and interpreting site signatures from disturbed contexts
}

\author{
JOHN M. STEINBERG*
}

\begin{abstract}
Are sites in lowland Europe destroyed when they are ploughed many times? In north Denmark, many Neolithic and Early Bronze Age sites are now reduced to just lithic scatters, but distinctive 'site signatures' persist. A lithic economic prehistory from the ploughsoil is possible and instructive.
\end{abstract}

In 1990, the Thy Archaeological Project (TAP) began an experiment to 'excavate' the ploughzone. In the years that followed we refined a methodology of recovering flakes and stone tools by mechanically screening large, discrete samples of ploughzone soil. We quantified prehistoric lithic activity using the distribution of the artefact frequencies in these samples. Our results confirm that ploughing neither completely destroys nor homogenizes sites into background noise. What is left after ploughing is not the 'site' familiar to archaeologists but rather a distinctive 'site signature' (Schofield 1991b). Site signatures enlighten us about the amount and type of lithic production that took place at each location. The striking result of an overview of site signatures in Thy, northern Denmark (FIGURE 1) is that most lithic production took place at a relatively few locations.

\section{Ploughzone paradoxes}

In Thy, over $75 \%$ of the area is under cultivation, typical for the fertile soils of lowland Europe (Haselgrove 1985; Lawson 1980). Cultivation, primarily ploughing, destroys the top $30 \mathrm{~cm}$ of archaeological sites (the ploughzone) by mixing, turning, and spreading out artefacts and strata ( $c f$. Dunnell \& Simek 1995; Hoffman 1985). The ploughing turns up and exposes the artefacts and features that make identification of prehistoric activity areas routine (Ammerman 1981; Haselgrove et al. 1985b; Mills 1985). Finding sites in ploughed fields is easy, but the ar- tefacts in the ploughzone are 'out of context' and nothing - it is thought - can be done with them (Asch 1975: $187 \mathrm{cf}$. Dunnell \& Simek 1995; Shott 1995). This is the ploughzone paradox.

Accordingly, the current practice in Danish contract archaeology is to remove the disturbed ploughzone (and most of the artefacts) to discover the truncated post-holes, pits and graves that outline prehistoric activity in undisturbed lower levels (e.g. Ethelberg 1991; Kristensen 1989; cf. Holm 1991). Shallow and ephemeral sites (Wood \& Johnson 1978) with little postoccupational soil deposition and no sub-surface features are found easily on ploughed agricultural land, but are not investigated further than their surface finds. Systematically excavated sites, preserved because they are in poor agricultural land or sealed by some chance processes, are the unusual ones; the shallow and ploughed sites need not be of the same character. We need to be able to 'excavate' shallow sites in good agricultural land in order to bridge the information gap between excavation and survey: we need to circumvent the ploughzone paradox.

\section{Surface survey and the ploughzone}

Surface surveys in ploughed fields are biased, so that even very intense, accurate surveys will not circumvent the ploughzone paradox. Surface survey is so coarse that those who conduct surveys have shied away from the concept

* Department of Anthropology, University of California, Los Angeles CA 90095, USA.

Received 25 October 1995, accepted 2 January 1996, revised 29 March 1996.

ANTlQUITY 70 (1996): 368-92 


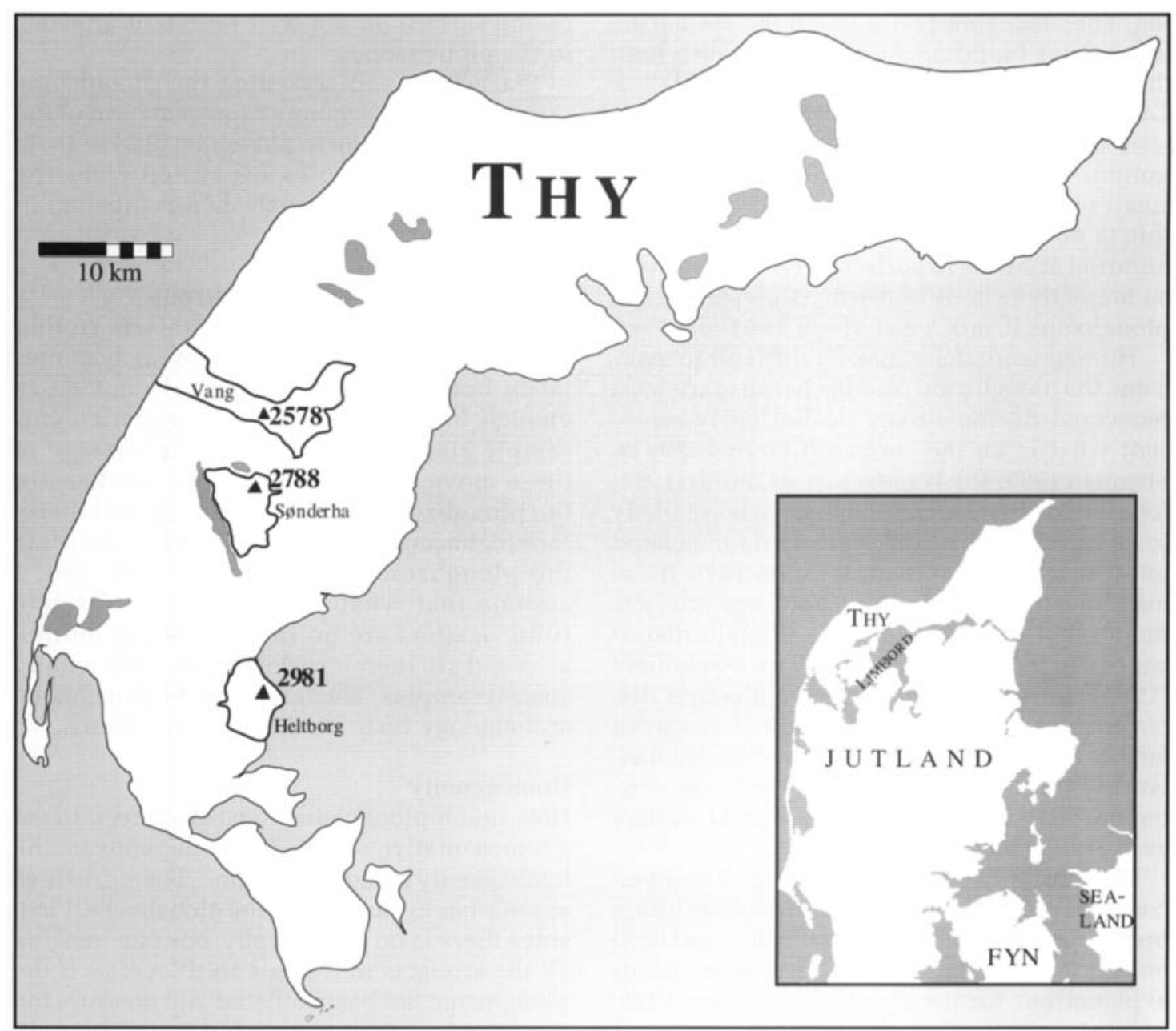

FIGURE 1. Thy, Denmark, with the parishes of Vang, Sønderhå and Heltborg outlined and the sites labelled $\triangle$

of a site, either in terms of habitation (Schofield 1991 b) or as any useful entity at all. Although many researchers think of site as a useful concept (e.g. Binford 1982; Cherry 1984; Dancey 1981; Ford 1987; Haselgrove 1985; Schiffer et al. 1978; Warren 1982), others involved in surface survey wish to view the archaeological record as a continuous but variable distribution of artefacts (e.g. Clark 1977; Dunnell \& Dancey 1983; Ebert 1992; Foley 1981a; 1981b; Gaffney et al. 1985; Plog et al. 1978; contributions to Rossignol \& Wandsnider 1992, especially Dunnell 1992; Thomas 1975). Surface survey is an excellent indicator of the presence or absence of archaeological remains. When present, the content and meaning of these re- mains is difficult to determine with surface survey data alone. Surface survey usually defines a landscape on the basis of artefact density, but survey can give a misguided impression of what is in the ploughzone (Richards 1985). Surface collection is not a methodology that allows us to circumvent the ploughzone paradox.

The sample size generated by surface survey can be too small to overcome the ploughzone paradox. The percentage of artefacts represented on the surface ranges from $0.3 \%$ (Clark \& Schofield 1991) to somewhat less than 15\% (Frink 1984), with most authors estimating 5-6\% (Crowther 1983; Lewarch \& O’Brien 1981a; 1981b; Shott 1995). Odell \& Cowan (1987) seeded a field with artefacts and surface-collected after plough- 
ing. They recovered only $2 \%$ of the seeded artefacts and found aggregation in areas where there was no seeded concentration. Odell \& Cowan suggest that this spurious aggregation is probably due to the surface collection's small sample size. If artefact densities are high, then small sample sizes need not be a problem, but this is rarely the case. To recover even a few hundred artefacts in surface survey, there must be many thousands of artefacts present in the ploughzone (Clark \& Schofield 1991: 95).

Human tendencies make it difficult to overcome the ploughzone paradox because artefacts recovered during survey do not fairly represent what is on the surface (Clarke 1979; $c f$. Shennan 1985: 43). Wandsnider \& Camilli (1992) found that clustered artefacts were more likely to be recovered by field-walkers than isolated ones, bright artefacts more often than those matching the ground colour, and large artefacts more often than smaller ones. Plough disturbance can increase this effect. Clark \& Schofield (1991) in their seeded surface collection discovered artefacts in clusters tended to spread farther ( $3.96 \mathrm{~m}$ average) than low-density scatters of flint $(1.71 \mathrm{~m})$. This may be because clusters are more visible on the surface and therefore easily collected.

Ploughing itself makes it difficult to overcome the ploughzone paradox. Ploughing brings up a disproportionately high percentage of large objects to the surface. There have been various explanations for the size effect (Backer 1978; Stockton 1973; cf. Odell \& Cowan 1987), but ploughing is partially designed to bring large rocks and soil clods to the surface so that clods can be disintegrated and large rocks removed (Ammerman 1985; Baker \& Schiffer 1975; Hughes \& Lampert 1979; House \& Schiffer 1975; Kouwenhoven \& Terpstra 1979; Lambrick 1977; Nartov 1984: 34), Lewarch \& O'Brien (1981b) find that artefacts seeded on the surface tend to move farther horizontally than those in the ploughzone soil matrix. Since larger artefacts will tend to be brought to the surface, and artefacts on the surface will tend to move farther, larger artefacts will move farther than smaller ones. Accordingly, artefacts obtained from the surface during fieldwalking will tend to be larger and to have moved farther from their original location than the average artefact (for specific examples see Bowers et al. 1983; Dunnell 1990; Roper 1976). Overall, artefacts on the surface do not well represent artefacts in the ploughzone.

Excavating and screening the ploughzone provides a more accurate representation of the site as it existed prior to ploughing (Barker 1975; Payne 1972). Samples excavated from the ploughzone do not have the biases inherent in surface collections.

\section{Finding pattern in the ploughzone}

Although ploughing moves artefacts so that their distribution over small areas becomes fairly homogeneous, artefacts do not move enough to destroy large-scale patterns. Our sample size and spacing take advantage of these movements. I assume that artefacts in the ploughzone are evenly mixed, and therefore that a small unbiased sample represents the ploughzone of the surrounding area. I assume that what were originally discrete lithic scatters are no longer sharply delineated and are therefore detectable with widely spaced samples. The feasibility of ploughzone archaeology rests on these assumptions.

\section{Homogeneity}

How much ploughzone must we screen to get a representative sample? That depends on the homogeneity of the ploughzone. There are three approaches to quantifying the ploughzone. First, since there is no stratigraphy, one can imagine all the artefacts in a single thin layer as if the ploughzone has been deflated and measure the density of artefacts per square metre. Second, since the ploughzone is constantly being mixed as if it is a fluid, we can sample from that fluid and estimate the density of artefacts per litre. More typically, the ploughzone is thought of as a solid, and therefore we would measure the artefacts per cubic metre.

Measuring in square metres assumes that all the flakes in the ploughzone were on the surface at a single time (Bradley 1987; Kintigh 1988: 961). From this point of view, what is important is that we have a sample size (in sq. $\mathrm{m}$ ) large enough be representative, but small enough not to blur distinctions; that is, not to combine what ought to be two different samples (Kish 1967). Nance \& Ball (1981), in surface pick-ups on ploughed fields, found that $2 \times 2-m$ squares were the smallest size in which differences could be isolated. Sample units larger than $2 \times 2 \mathrm{~m}$ are inefficient and probably mask variation. 
Archaeologists are used to thinking of artefact densities per cubic metre. In this description of density, the amount of soil that has accumulated is relevant because it demonstrates the difference between, say, a clean floor and a midden. Unfortunately artefact density per cubic unit of ploughzone tells us little. Allen (1991) showed that artefact densities are unreliable where soil has been added or subtracted. Because the ploughzone can be highly irregular, cubic densities are hard to estimate. But we must measure the ploughzone as some sort of volume; let us treat the ploughzone as a fluid, spread out across the subsurface. We can therefore mix it up and measure it in buckets, a practical measure. Technically, there is no difference between 1000 litres and 1 cubic $m$, but a quantification of artefacts per litre implies that the number of litres containing artefacts in a given area of ploughzone is important (i.e. the depth of the fluid containing artefacts is a relevant variable). In order to set a standard (English Heritage 1995: 16; Shott 1992: 11) I will report sample densities in litres and use the density per square $m$ in estimating the total number of flakes.

How many litres make up a representative sample of a 4-sq.-m section of ploughzone? Because even a few ploughings make the artefact distribution relatively homogeneous, the number of litres that fairly represents the ploughzone in that area depends on the density of artefacts (Plog \& Hegmon 1993). Ploughzones are usually about $30 \mathrm{~cm}$ deep; therefore a $2 \times 2$ $m$ section will contain 1200 litres of soil. By experiment we found that $100 \mathrm{l}$ of soil was sufficient to get an accurate cubic density of abundant artefacts (e.g. flakes). As we were interested in recovering less common artefacts, we settled on $400 \mathrm{l}$ of soil per sample (Kintigh 1988: 701).

\section{The Machine}

In order to process the 400 litres of soil in each sample we built a mechanical screener, fondly termed The Machine (FIGURE 2). The Machine is is a triangular shaped square metre of 1-sq.$\mathrm{cm}$ mesh, angled at about $5^{\circ}$. The screen is fastened at both ends by rubber shock absorbers to a metal cube. Powered by a 5 h.p. Briggs \& Stratton engine through a belt clutch and flywheel assemblage, the screen shakes back and forth 2-5 times a second. Soil dumped into the top end moves downward by the rocking mo- tion of the screen. The wood box surrounding the screen, open at the small lower end, permits the material that did not go through the screen to be dumped on to a sorting table.

The Machine required two people: one to shovel, one to pick out the artefacts from the material that did not go through the screen (FIGURE 3). Upon completion of a 400-l sample, the screen and sorting table were cleaned and the artefacts bagged. Each 400-l sample took 1530 minutes to process. Once the artefacts from a ploughzone sample were recovered, they were washed and catalogued. Initial cataloguing consisted simply of counting the number of stone tools and flakes. Few ceramic, bone or other fragile artefacts are recovered from the ploughzone.

\section{Movement}

The nature of artefact movement in the ploughzone determines sample spacing. Without redundancy, samples must indicate overall trends and isolate high-density areas. Experimental studies of seeded artefacts and ploughing have convincingly quantified the movement of artefacts in the ploughzone (Gingell \& SchadlaHall 1980; Talmage \& Chester 1977; Trubowitz 1978; cf. Ammerman 1981). Lewarch \& O'Brien (1981b) seeded over 6000 artefacts in three patterns, each containing three different artefact sizes. They ploughed from one to three times, then surface-collected the area. They found that short-term ploughing moved artefacts an average of $40 \mathrm{~cm}$ perpendicular to the plough and less than $3 \mathrm{~m}$ in the plough direction. Ammerman (1985) demonstrated a much greater average displacement, for he placed large tiles on the surface; after over 20 ploughings most tiles had moved at least $5 \mathrm{~m}$, and many had moved $15 \mathrm{~m}$.

Upon initial ploughing of a site, the artefact scatter expands relatively quickly (Bowers et al. 1983). Theoretically, the spread reaches a point when further movement of artefacts becomes negligible and the rate of site expansion drops to almost nothing (Hoffman 1982: 304; Lewarch \& O'Brien 1981a). Odell \& Cowan (1987) looked for 'equilibrium' in the average displacement of artefacts. Using a seeded field that was ploughed and disked 14 times, they found that the initial ploughings created most of the displacement. By the third ploughing/ disking period the average displacement was 


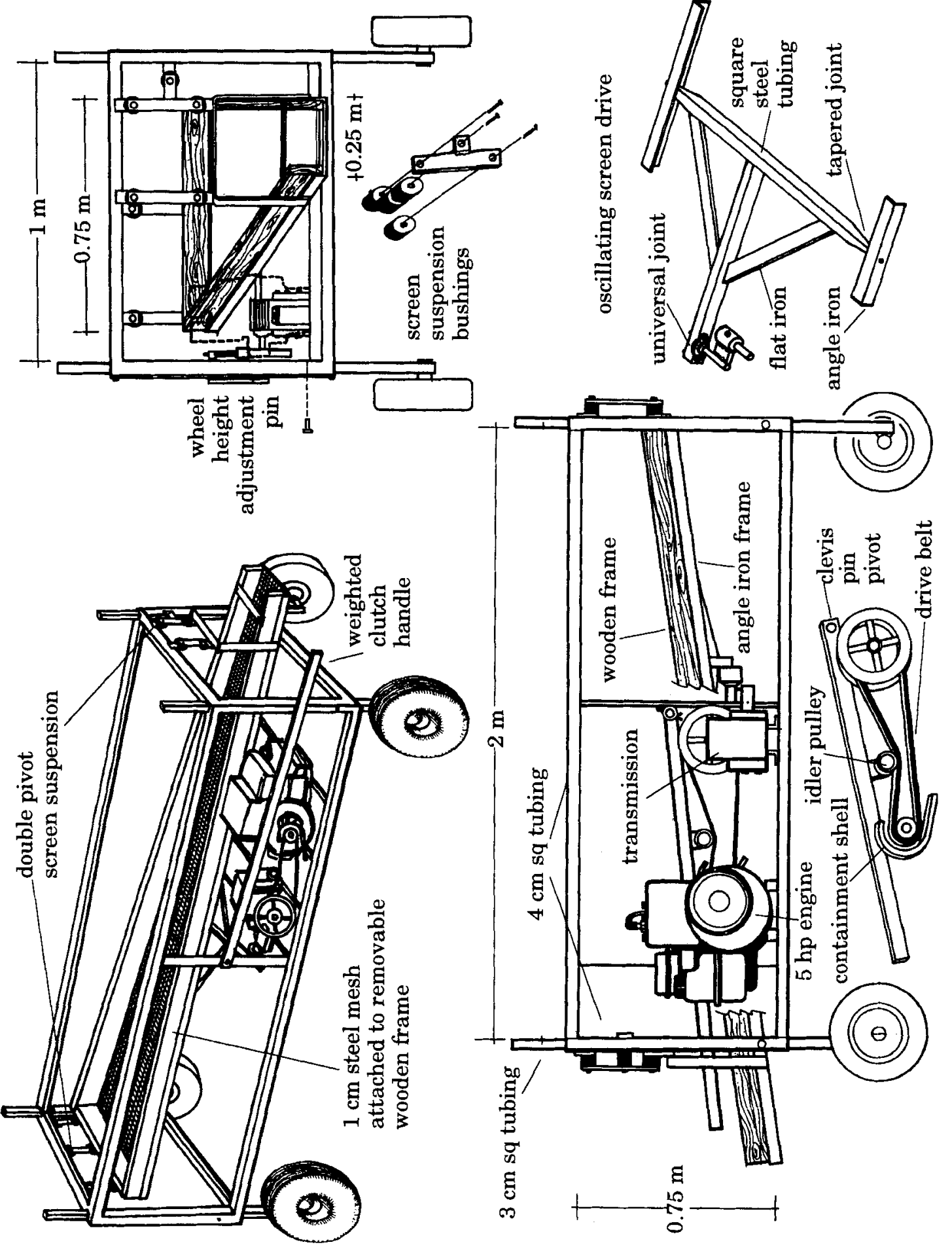

FIGURE 2. The Machine. 


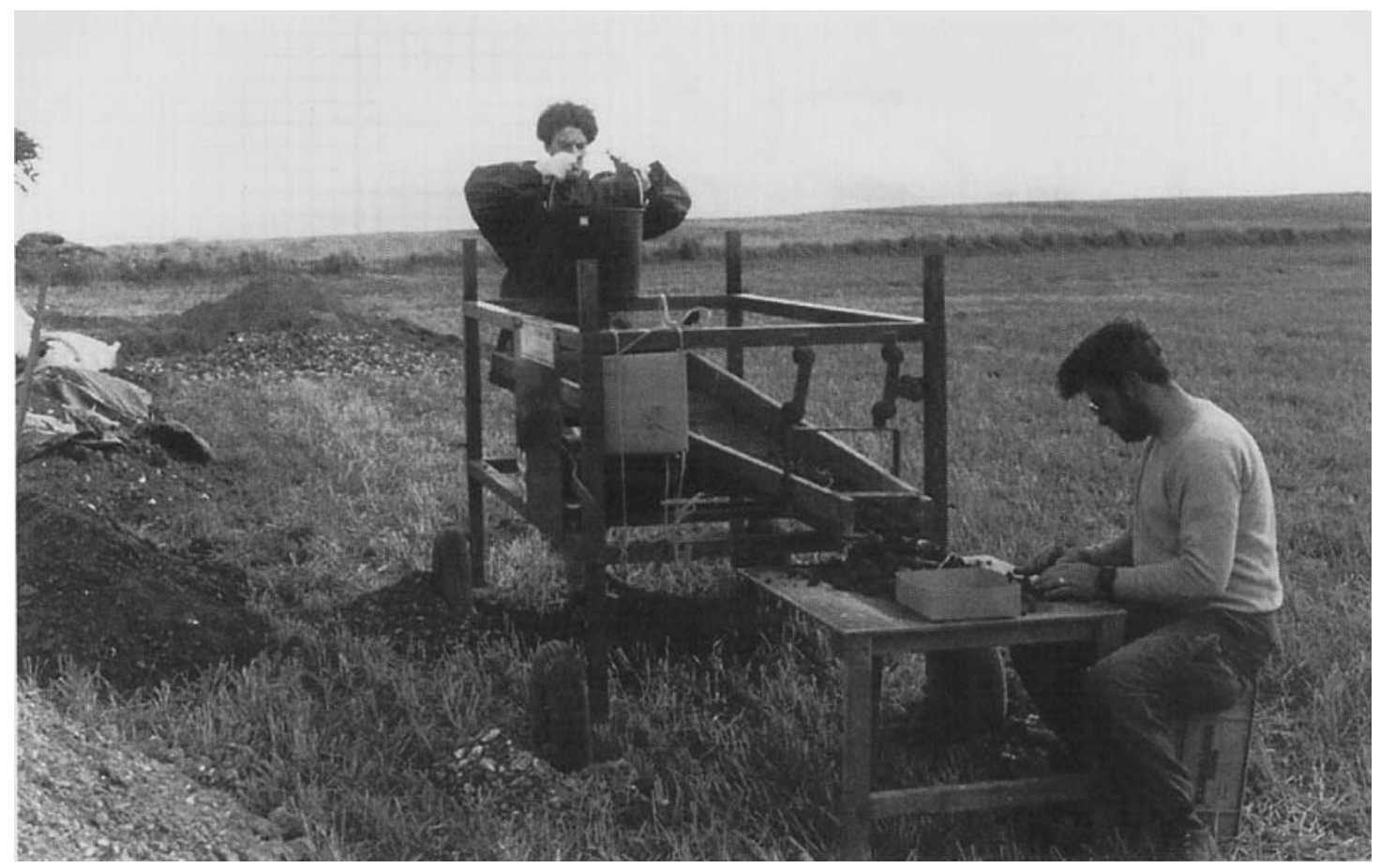

FlGURE 3, Running The Machine at THY 2920.

already over $2.5 \mathrm{~m}$. Over the 14 ploughings the seeded site more than doubled in size from over 200 sq. m to almost 500 sq. m. Although Odell \& Cowan felt that 14 agricultural treatments was too few for a constant average displacement to set in, 'equilibrium' was not far off. Because of the non-random nature of ploughing, the average displacement of artefacts should become constant ( $c f$. Dunnell 1990; Yorston 1990). Clark \& Schofield (1991) had similar results; over three seasons and six agricultural treatments, the maximum displacement for flakes was $3.7 \mathrm{~m}$ with an average of $1.2 \mathrm{~m}$. These figures were much smaller for rounded pebbles. The average displacement will be asymptotic; as artefacts are moved back and forth, average displacement will level out at somewhere between 3 and 15 $\mathrm{m}$. Computer simulations using random walks of 3000 ploughings indicate the average movement is less than $5 \mathrm{~m}$ (Bowers et al. 1983; Haggett 1965). While sites may double in size, they will not triple or quadruple.

Assuming that we understand the correct sample size needed to characterize the surrounding ploughzone, average displacement of artefacts indicates that samples placed any closer than $4 \mathrm{~m}$ apart will be redundant. Samples placed further than $20 \mathrm{~m}$ apart have a distinct possibility of missing concentrations. In areas of high concentration, samples close to the minimum will provide increased resolution. On the other hand, in areas of low concentrations, additional samples provide almost no new information.

In 1991 TAP experimented with various ploughzone sampling strategies, with the limitation of spending no more than four to five days at a single site. At one site we placed samples randomly. Like Redman \& Watson (1970: 281), we found that with a small number of samples, large areas went untested - not helpful when studying the spatial distribution of lithic material. Systematic sampling is only unreliable when there is a sinuous distribution, which we felt unlikely; therefore we amalgamated the shovel testing methodology proposed by Krakker et al. (1983; see also Kintigh 1988) with 50x50m survey blocks into an 'offset-3 pattern' (FIGURE 4). This arrangement is some $7 \%$ more efficient than an entirely square grid.

The offset-3 pattern has other advantages. It is easy to set up, uses whole numbers, and 

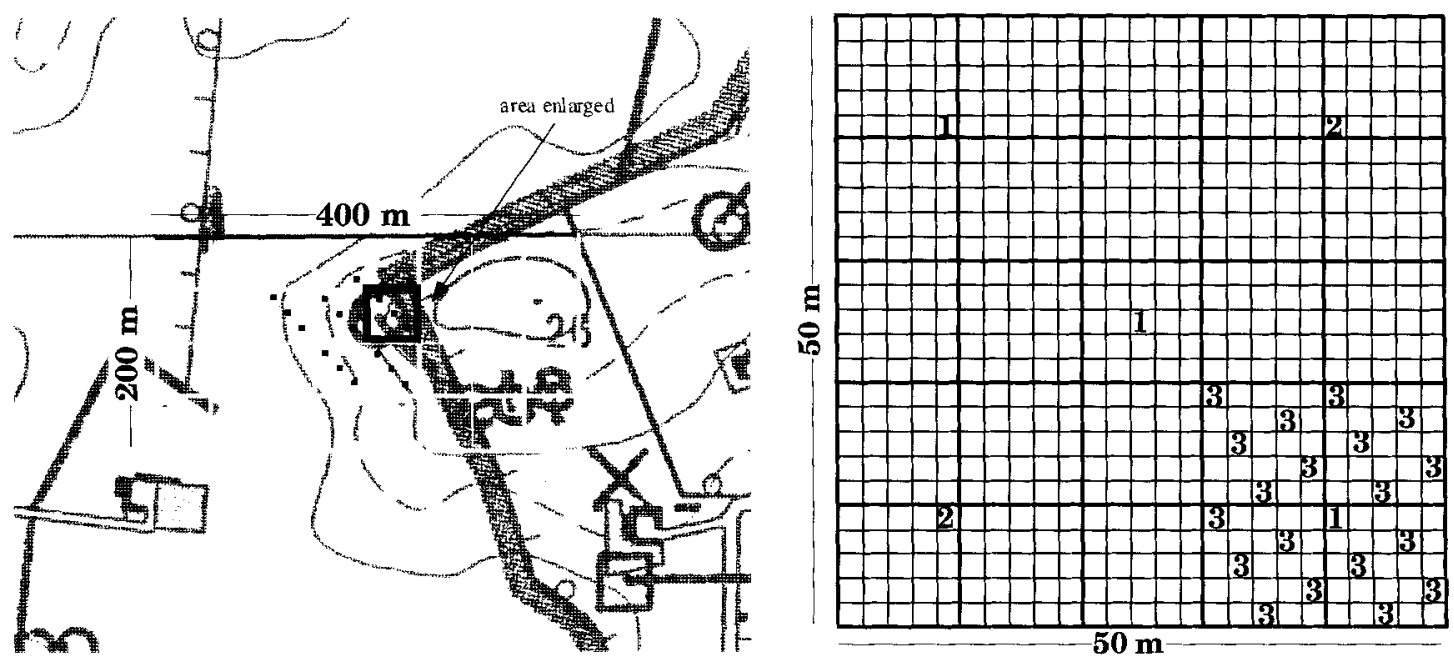

FIGURE 4. The offset-3 pattern laid out at THY 2788. The ideal 50x50-m block is shown with $2 \times 2-m$ primary (1), secondary (2), and tertiary (3) ploughzone samples.

can be repeated with exactly the same pattern. The uneven edges of a sampled area increase our ability to sample the periphery of sites by taking advantage of the edge effect (Abbott 1985; Nance 1983). When high-density spots are found, the samples can be intensified, first to five (secondary ploughzone samples) and then to 125 ploughzone tests (tertiary ploughzone samples) within the block structure (FIGURE 4). Rapid lab processing that leads to the computergenerated density distributions is critical as a guide in placing secondary and tertiary ploughzone samples. It is almost impossible to obtain ploughzone samples once the machines have begun to scrape and look for post-holes. The offset-3 pattern gives us consistent coverage, so that all but the smallest activity areas that contain significant numbers of artefacts will be sampled.

\section{Limitations}

The ploughzone sampling methodology does have limitations and I wish to make these explicit. The samples are cluster samples, placed judgementally, in sites where the artefact density is usually autocorrelated. The result of this practical methodology is that it is difficult to judge the accuracy of the estimates with statistical procedures.

Due to the screen-size employed, we recover almost none of the debitage smaller than $1 \mathrm{~cm}$. Estimates of the percentage of flakes that would go through a 1-cm mesh vary from $38 \%$ (Hansen
\& Madsen 1983) to $78 \%$ (Stahle \& Dunn 1982). The missing percentage, large in terms of numbers, is a relatively small percentage of the total weight of debitage. Screened ploughzone samples offer a minimal picture of resharpening and other activities that produce small flakes in the final stages of production.

The sheer magnitude of flint in the Danish moraine and the speed at which The Machine operates makes recovery of anything other than conchoidal flakes unlikely. This means that we know little of the initial stages of production (e.g. if bipolar techniques were used). The method limits the questions we can ask of the data - we are restricted to studying production at its intermediate stages.

Damage to the individual artefacts is widespread in the ploughzone, and if artefacts are fragile, they are destroyed. Studies show that over 10 years of continuous ploughing the average sherd size decreased by $90 \%$ (Reynolds 1982 cf. Dunnell \& Simek 1995). Almost all microwear traces on ploughzone artefacts are destroyed (Aperlo 1994). As for the sturdier stone tools, Roper (1976) found that the mean displacement of tools that had been broken and separated by ploughing was less than $2 \mathrm{~m}$ and that the plough damage was fairly obvious. Knoerl \& Versaggi (1984) found that ploughing does not change the ratio of broken to whole tools. However, the 11:1 ratio of pristine:ploughedge-damaged blades determined by Knoerl (1976), cited in Knoerl \& Versaggi (1984), does 
not seem compatible with Mallouf's (1982) exhaustive determination that over $90 \%$ of artefacts in the ploughzone are plough-damaged.

All sites contain the remnants of multiple behaviours. At some point, the sum total of the multiple behaviours preserved no longer constitutes a site but rather a 'palimpsest' (Carr 1985; Zvelebil et al. 1992: 196). As the analogy of disturbed multiple occupation sites with erased and re-lettered manuscripts is not helpful, instead I use the term 'multiple component' (Riordan 1982). We avoid ploughzone-sampling sites with high percentages of diagnostic artefacts from two distinct time-periods. A ploughzone-tested multiple-component site tells us little more than a well-done surface survey. In Thy, ploughzone sites that contain significant numbers of artefacts from two distinct periods are infrequent.

\section{Site signature}

Schofield, in defining a signature, felt that regularities in prehistoric human behaviour should be visible through surface collection (1981b: 5):

Signatures in the form of artefact scatters will occur, the one proviso being that material remains were the end-product of a given aspect of human behaviour. So long as those remains have survived the passage of time, the patterns should be there. The onus is on us to interpret those patterns and to understand precisely what it is they represent, whether settlement activity, quarrying or manuring.

Surface survey is accurate enough to provide a qualitative description of surface scatters and associate them with gross differences in human behaviour. I believe we can go even further. Ploughzone sampling is accurate enough to provide a quantitative assessment of lithic scatters that detail the different types of lithic activities that took place. A lithic scatter is the sum total of the preserved behaviours - a quantified lithic scatter is a site signature. A site signature highlights the variability in lithic scatters that is masked by surface collections. Quantifying the variability of site signatures can refine our understanding of prehistoric human behaviour.

A site signature is a series of numbers, percentages and distributions: how many artefacts, what kind of artefacts, how those artefacts are distributed in space. The primary component of a site signature is the flake. A site signature describes the total number, weight and kind of flakes, as well as the number of tools, and the ratio of tools to flakes. These counts, percentages and ratios create a picture of the kinds and proportions of lithic activities that went on at a site.

The area of a site signature must be defined by the distribution of artefact frequencies, even when there are preserved subsurface remains (Richards 1985: 32; $c f$. Shott 1995: 476). Usually, artefact concentrations have a distinct falloff which defines the site (Woodward 1978); if not, the site is defined by the extent of ploughzone tests. If most of the artefact-bearing strata have been incorporated into the ploughzone, then a site signature is a consistent description of the lithic remains. A comparison of site signatures across a region yields the variability in lithic production and consumption.

\section{Quantification}

The ability to get at behavioural patterns from the quantification of lithic remains, especially flakes, has been realized. I follow Shott's (1994) recommendations that we combine flakes and tools to arrive at an overall picture of behaviour that relates to stone-tool production and use. Thus, we quantify broad categories of artefacts and calculate their frequency over a site, which gives us the raw stuff of a site signature. The goal is to understand how the amount and efficiency of lithic production correspond with use of stone tools.

\section{Artefact attributes}

The most numerous prehistoric artefact found in the ploughzone is the flake. As an aggregate, flakes are the most revealing remnants of production (Shott 1994). Much of the work with flake size has been done by size-grading (Ahler $1986 ; 1989$ ). As a trial, we size-graded two sites with very different average flake weights (FIGURE 5). The whole flakes at THY 2788 (Early Bronze Age) have an average weight of $4.1 \mathrm{~g}$, the flakes at THY 2981 (Early Neolithic) an average weight of $6.7 \mathrm{~g} .{ }^{1}$ We found, predictably, that the site with heavier flakes contained a higher proportion of large flakes both by weight

1 Because the flakes are not weighed individually we can only do a $t$ test with the average weight of the ploughzone samples. THY 2788 has a SD of $1 \cdot 2$, THY 2981 has a SD of $2 \cdot 5$. With 49 degrees of freedom the difference is highly significant. 


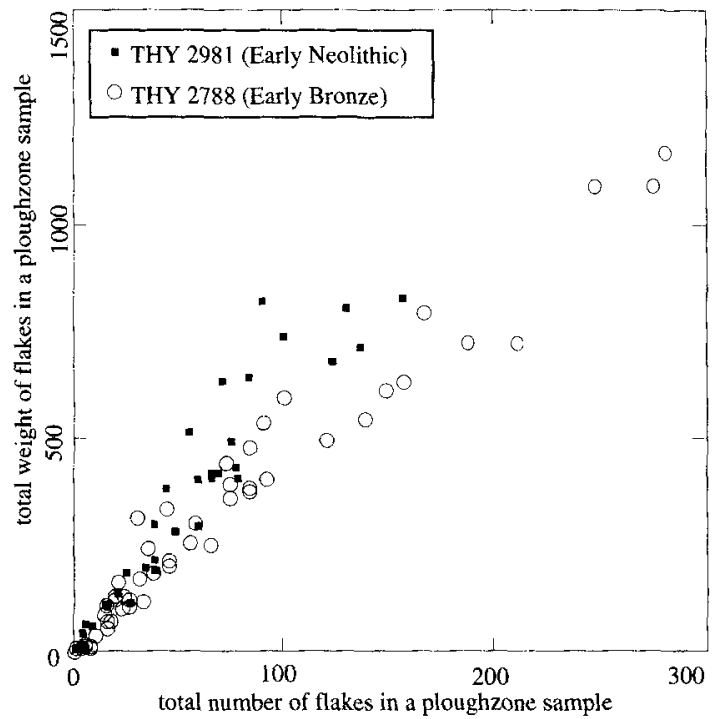

FIGURE 5. The total number and weight of flakes from 400-l ploughzone samples at THY 2981 and THY 2788.

and by count (TABLE 1). However, a comparison of the two sites using a cross-tabulation of the percentage of cortex by size grade indicates little difference between the two sites (TABLE 2 ). The top four combinations, medium and small flakes with little or no cortex, appear in the same order, at approximately the same percentages in both sites. From this study, we concluded that size-grading and estimating the amount of cortex tell us little more than the average weight of flakes. Ploughing, extensive occupation, similar raw material, and our coarse recovery hide any differences in the frequencies of lithic production modes. To move beyond simple characterizations of the count and weight, we have divided flakes into very basic groups, while lumping tools together. These

$\begin{array}{llrrrr}\text { site } & \text { flake size } & \text { count } & \% & \text { weight (g) } & \% \\ & & & & & \\ \mathbf{2 7 8 8} & <0 \cdot 25^{\prime \prime} & 305 & 27 \cdot 2 & 355 & 8 \cdot 4 \\ & 0 \cdot 25^{\prime \prime}-1 " & 797 & 71 \cdot 2 & 3497 & 82 \cdot 2 \\ & >1 " & 18 & 1 \cdot 6 & 402 & 9 \cdot 5 \\ \text { total } & & 1120 & & 4254 & \\ & & & & & \\ 2981 & <0 \cdot 25 " & 272 & 23 \cdot 1 & 237 & 3 \cdot 4 \\ & 0 \cdot 25^{\prime \prime}-1 " & 814 & \mathbf{6 9 \cdot 0} & 4198 & 59 \cdot 9 \\ & >1 " & 94 & 8 \cdot 0 & 2579 & 36 \cdot 8 \\ \text { total } & & 1180 & & 7014 & \end{array}$

TABLE 1. Flakes at THY 2788 and THY 2981: counts and weights for small, medium and large flakes.

categories inform us about the amount and efficiency of production, and the amount of stonetool use.

The natural division of Danish lithic material is between flint found in Maastrichtian (Cretaceous) chalk and Danian (Tertiary) chalk (Bagge Johansen 1987) although identification is not always easy (Nielsen 1993). Danian flint is primarily used in the Middle Neolithic thickbutted axes (Peterson 1994) but makes up a relatively small proportion of those assemblages (no more than $4 \%$ ). Most (99\%) of the flint is Maastrichtian which we subdivided into:

1 retouched flakes,

2 burnt flakes,

3 whole flakes,

4 broken flakes, and

5 chunks,

in that order. In theory, these categories can overlap (Ensor \& Roemer 1989; $c f$. Sullivan \& Rozen 1985). However, they are to be understood in the order of importance. Retouch is the most important category: a broken retouched flake will go in the retouched category, a burnt whole flake will go in the burnt category. site flake size

$\begin{array}{llrr}2788 & <0 \cdot 25^{\prime \prime} & 127 & 10 \cdot 8 \\ & 0 \cdot 25^{\prime \prime}-1 " & 317 & 26 \cdot 9 \\ & >1 " & 18 & 1 \cdot 5 \\ 2981 & <0 \cdot 25^{\prime \prime} & & \\ & 0 \cdot 25^{\prime \prime}-1 " & 154 & 13 \cdot 8 \\ & >1 " & 344 & 30 \cdot 7 \\ & & 2 & 0 \cdot 2\end{array}$

dorsal surface of flakes covered by cortex

\begin{tabular}{rrrrrr}
\multicolumn{2}{c}{$1 / 3$} & \multicolumn{2}{c}{$2 / 3$} & \multicolumn{2}{c}{ all } \\
count & \multicolumn{1}{c}{$\%$} & count & $\%$ & count & $\%$ \\
& & & & & \\
102 & $8 \cdot 6$ & 19 & $1 \cdot 6$ & 24 & $2 \cdot 0$ \\
330 & $28 \cdot 0$ & 89 & $7 \cdot 5$ & 78 & $6 \cdot 6$ \\
48 & $4 \cdot 1$ & 10 & $0 \cdot 8$ & 18 & $1 \cdot 5$ \\
& & & & & \\
112 & $10 \cdot 0$ & 23 & $2 \cdot 1$ & 16 & $1 \cdot 4$ \\
350 & $31 \cdot 3$ & 51 & $4 \cdot 6$ & 52 & $4 \cdot 6$ \\
12 & $1 \cdot 1$ & 1 & $0 \cdot 1$ & 3 & $0 \cdot 3$
\end{tabular}

TABLE 2. Cortex at THY 2788 and THY 2981: counts for varying proportions of cortex. 
1 Retouched flakes, from the ploughzone, can be a dubious category (Malloff 1982). Plough damage can look like, and be caused by, essentially the same forces as purposeful prehistoric human retouch. In identifying retouched flakes, we have been conservative. Retouch is an indicator of lithic use on that particular spot.

2 Burnt flakes, although high in the hierarchy, lose much of their information in the burning process. They will not be discussed here.

3 The raw number of whole flakes is a good index of lithic production. Sites with relatively low percentages of whole flakes were probably not involved in stone-tool production on a large scale.

4 The meaning of broken flakes in the literature is unclear (Gardiner 1987: 69). Sullivan \& Rozen (1985) distinguish between broken flakes and flake fragments. I have lumped broken flakes and flake fragments together, following Fish (1981) who divides flakes into those that have all measurable dimensions present and those that do not. Sullivan \& Rozen, however, found much higher percentages (upwards of $35 \%$ ) of broken flakes than we did in the ploughzone samples. This may be for any or all of three reasons: we may not be identifying broken and flake fragments in the field; the material is of very high quality and there is a lower percentage of broken flakes overall; or, our 1-cm mesh might eliminate a large proportion of smaller broken flakes. Sullivan \& Rozen (1985) believe that their high percentage of broken flakes is not due to trampling but is instead a technical indicator of lithic production. Many other authors disagree. Some feel that trampling can increase the number of broken flakes, even in soft soil (Cotterell \& Kamminga 1979; 1987; Prentiss \& Romanski 1989: 94) while others see more insidious forms of damage and edge wear (Flenniken \& Haggerty 1979; Tringham et al. 1974). I will use increased numbers of broken flakes as an index of trampling (see Fischer et al. 1979; cf. Fish 1979).

5 An unequivocal indicator of lithic production, while at the same time one of the more unclear categories, is the chunk.

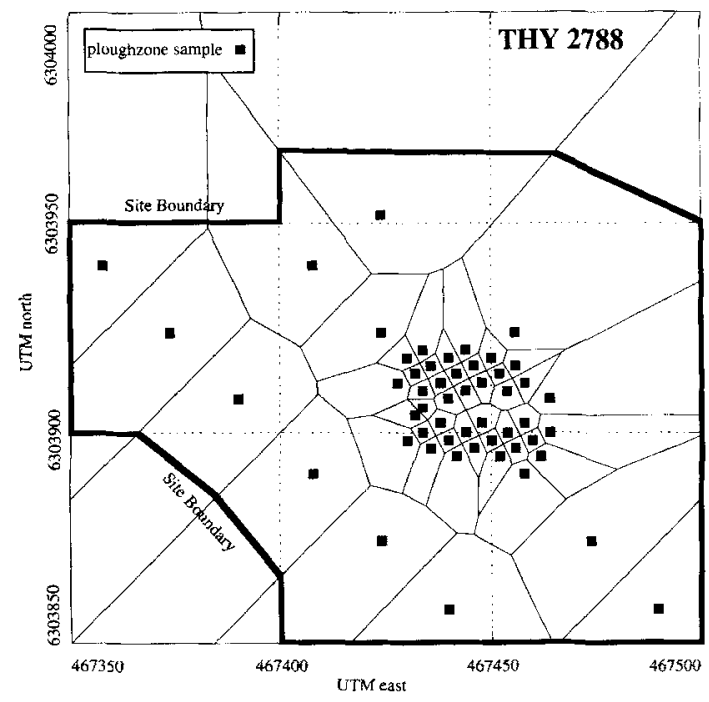

FiguRE 6. Thiessen polygons for each ploughzone sample at THY 2788.

Chunks are either blocks with a flake or two taken off, or what appears to be bipolar shatter. This category is a good indicator of the roughness of the production. The more chunks present, both absolutely and as a percentage, the more likely that the initial stages of production were taking place.

\section{Site attributes}

The site signature primarily consists of the distribution of flake frequencies. There are several methods for estimating the total population of various artefact classes for a sampled area of a given site, each of which provides similar results. Using THY 2788 as an example (FIGURES 6 \& 7), the primary ploughzone tests constitute a systematic sample. Taking an average of 21.3 flakes per sq. $m$ over 1.25 ha yields 239,600 flakes. The primary, secondary and tertiary samples constitute a stratified sample based on sample density which yields 230,250 flakes. The tests can also be stratified by $50 \times 50-$ m block which yields 228,850 flakes. Finally, and probably most accurately, each sample can be assigned its Thiessen polygon (FIGURE 6), generated by the SYSTAT computer program. The edges of the polygons have been cropped so that no polygons represent more than 2500 sq. m. Under this method we arrive at 237,300 flakes. To get accurate confidence intervals, we 


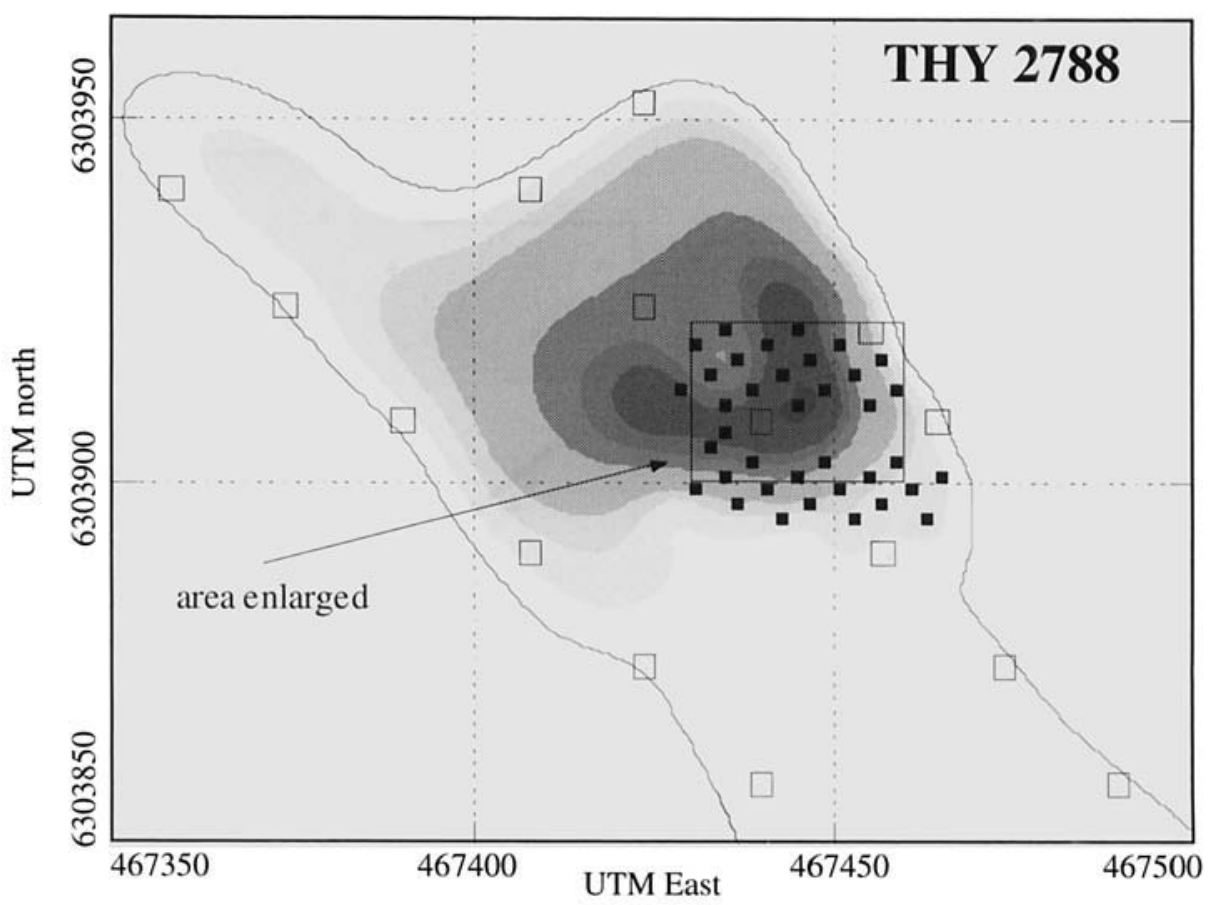

10 flakes $\mathrm{m}^{2}$

20 flakes $\mathrm{m}^{2}$

30 flakes $\mathrm{m}^{2}$

40 flakes $\mathrm{m}^{2}$

60 flakes $\mathrm{m}^{2}$

80 flakes $\mathrm{m}^{2}$

100 flakes $\mathrm{m}^{2}$

150 flakes $\mathrm{m}^{2}$

200 flakes $\mathrm{m}^{2}$

$\square 1992$ sapmle

- 1993 sample

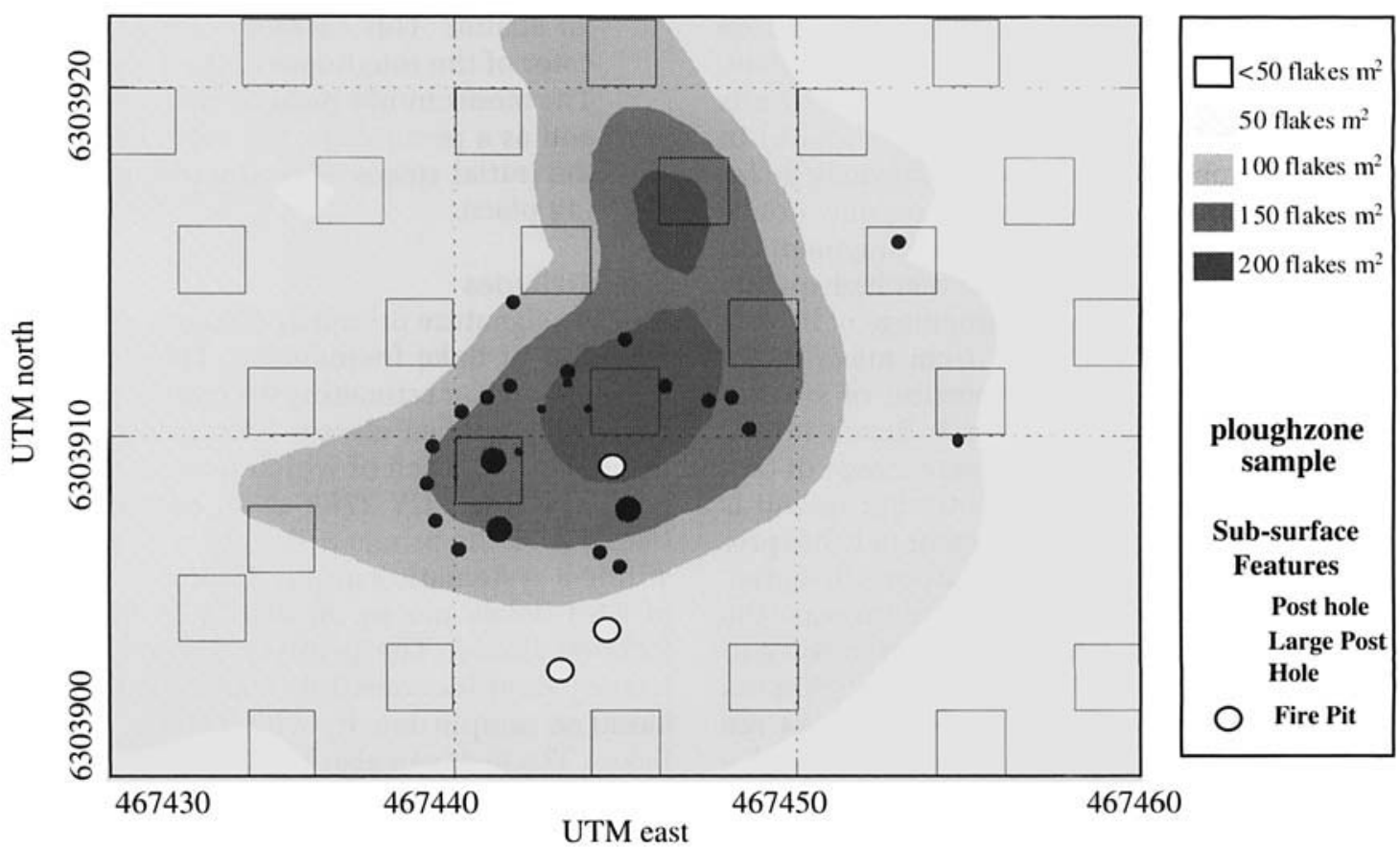

FIGURE 7. Flake distribution at THY 2788. The UTM grid numbers are metres from the prime meridian (east) and the equator (north). The darker the shading the higher the number of flakes per sq. $m$.

should take random samples over the whole tical. By augmenting a binomial distribution, area. As discussed above, this proved imprac- we can estimate the minimum variance and 
hence obtain some idea of the confidence interval (APPENDIX). Using this procedure at THY 2788 , we have a minimum of $\pm 16,000$ flakes with a $95 \%$ confidence interval.

The three sites used as examples below have been completely analysed. The percentages and totals were arrived at by multiplying the number of artefacts and flake types per sq. $m$ in each sample by the area of its polygon. Included in this multiplication are any substantial and consistent differences in the depth of the ploughzone. We intensively analysed the spatial distribution of the absolute and relative amount of various classes of flakes and artefacts, and could detect no obvious spatial pattern beyond the distribution of the total number of flakes.

The homogeneity of samples within a site allowed us to reduce the analysis necessary to arrive at the percentages and totals of flake categories. Rather than analyse each sample we divided the samples into quartiles, by absolute and calculated total number of flakes, and selected the top sample from each quartile for intensive analysis. Therefore, at least 4 but no more than 8 samples were analysed at a single site. A comparison of the abbreviated analysis with the fully analysed sites demonstrates that there is not more than a fifth of a percentage point differences in the flake categories, and average weight varies by no more than twotenths of a gram. The results of the abbreviated analysis are presented in TABLE 3 .

For the purposes of this analysis, all diagnostic tools are lumped together, while flakes are split into various categories. This might seem odd, as diagnostic tools are just that - diagnostic - - while flakes are usually considered un-diagnostic. I reverse this typical stone tool outlook and consider tools to be the last stage in the economic flint cycle (Shott 1994). Tools are subject to the most endogenous forces, that is, forces that do not relate directly to the site in question. Prehistoric curation and collection (Bamforth 1986), off-site use and discard produce variable results, while production behaviours are remarkable similar (Murray 1980; Yellen 1977). More importantly, tools are far less frequent. Tools and cores together comprise no more than $15 \%$ of an assemblage, with any functional category of tool making up less than $1 \%$ of a total assemblage.

Estimates of the number of cores and the ratio of flakes per core should not be relied upon, as these artefacts are scarce and Neolithic and Early Bronze Age lithic industries are not core industries. In many cases the difference between a core and a chunk, discussed above, is quantitative: cores have more flake scars. The number of cores is usually well correlated with the number of chunks, indicating that maybe we should combine them.

The ratio of flakes to tools gives us some idea of the efficiency of stone-tool production (Christenson 1982). When making an assessment of efficiency, the absolute number of both flakes and tools must be taken into account. Sites with a low ratio of flakes to tools with high numbers of both (e.g. THY 1535) indicate efficiency. Sites with the same low ratio but low absolute numbers (e.g. THY 2578) are probably end-user sites (TABLE 3).

\section{Examples of site signatures}

I will use three prehistoric habitation areas as examples of individual site signatures. The three sites are from different time-periods, have diverse lithic remains, and were sampled at varying intensities (TABLE 4). The sites are comparable because most of their artefacts are in the ploughzone; they were excavated as described above.

\section{THY 2788 in the parish of Sønderhå}

The area around THY 2788 was first described in the parish survey of 1873-1930 (Kristiansen 1985). Brunsendorff surveyed the land in 1912, describing THY 2788 (SB 208) as a small, ploughed-over mound. He gave neither a date nor a description of any artefacts from the area. In the 1980s, the area around SB 208 was extensively walked by a school teacher who found a number of asymmetrical sickles distinctive of the Early Bronze Age (Petersen 1993), and a light lithic scatter west of Brunsendorff's 'mound'.

In 1992 TAP investigated the area, first with some shovel tests and then with a broad swath of 15 ploughzone tests in an area of almost 1.5 ha (Bech et al. in press). One ploughzone test had almost 300 flakes in its $400 \mathrm{l}$, and another just $15 \mathrm{~m}$ away had almost 100 flakes. At the end of the 1992 season we cleared the ploughzone away from a small area where 4 post-holes were clearly visible. In the 1993 field season, we took 37 additional ploughzone samples in the tertiary pattern around the area of post-holes and lithic debris (FIGURE 7). 


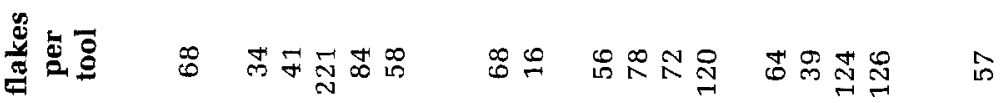

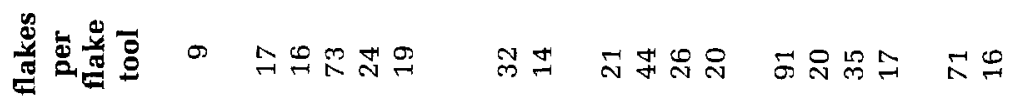

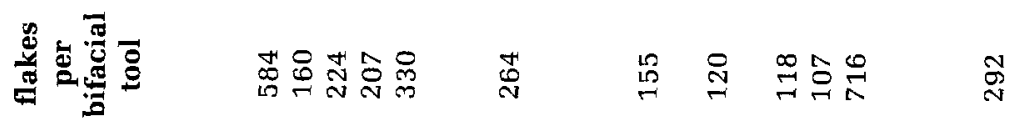

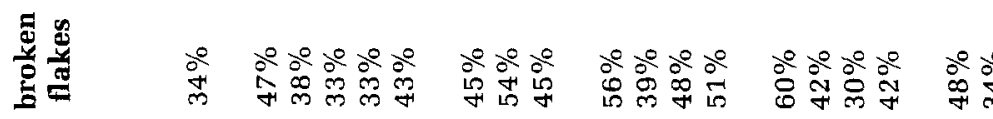
宽

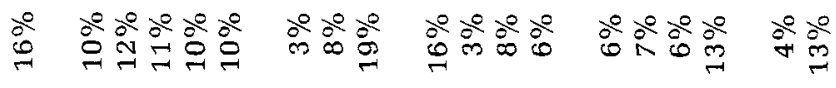

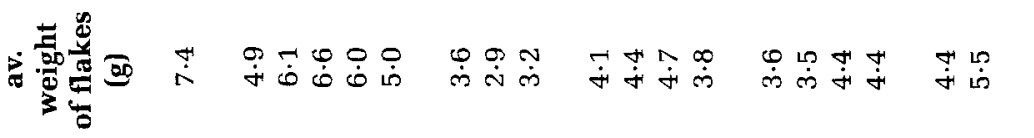

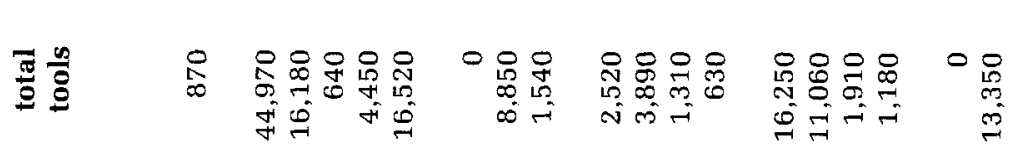

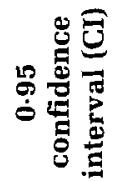

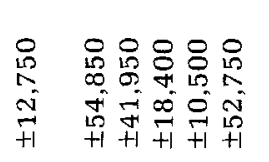
8 용 ง. 2.

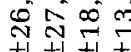

0008 요융

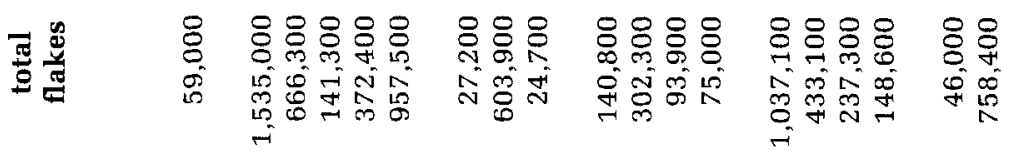

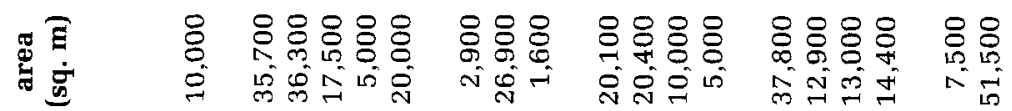

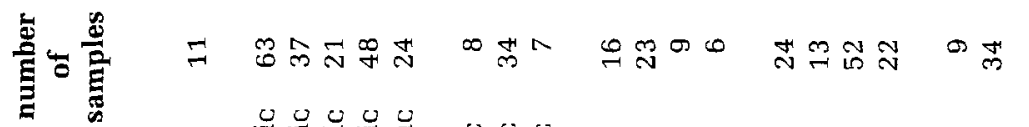

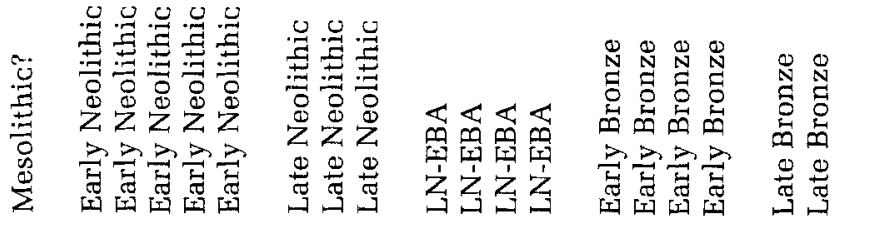

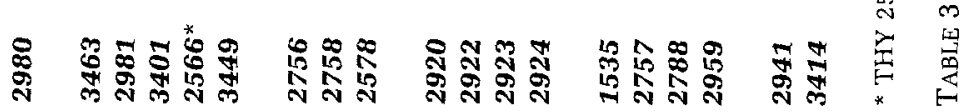


site

age

flakes

total number

high per $\mathrm{m}^{2}$

average per $\mathrm{m}^{2}$

average weight of flakes

total weight $(\mathrm{kg})$

whole flakes

average weight

by count

by weight

total count

total weight $(\mathbf{k g})$

retouched flakes

average weight

by count

by weight

total count

total weight (kg)

broken flakes

average weight

by count

by weight

total count

total weight $(\mathrm{kg})$

average weight of chunks

count of chunks

average weight of burnt flakes

count of burnt flakes

average weight of Danian flakes

count of Danian flakes

tools

scrapers

sickles

axe fragments

cores
2981

Early Neolithic

666,000
118
18
$5 \cdot 9$
3925

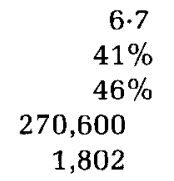
$10 \cdot 1$
$11 \%$
$20 \%$
76,500
774

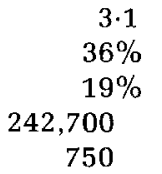

$6 \cdot 5$

$6 \%$

$6 \cdot 6$

$3 \%$

$12 \cdot 6$

$2 \%$

$$
\begin{array}{r}
16,180 \\
8,200 \\
0 \\
3,560 \\
23,850
\end{array}
$$

2578

Late Neolithic

24,700

19

15

$3 \cdot 2$

80

$\begin{array}{rr}3 \cdot 4 & 4 \cdot 1 \\ 32 \% & 58 \% \\ 33 \% & 54 \% \\ 7,800 & 138,000 \\ 27 & 560\end{array}$

$\begin{array}{rr}5 \cdot 8 & 9 \cdot 3 \\ 19 \% & 6 \% \\ 34 \% & 12 \% \\ 4,700 & 13,700 \\ 24 & 127\end{array}$

11,150

24

$3 \cdot 8$

$3 \%$

0.5

$2 \%$

$0 \%$

$$
\begin{array}{r}
1,540 \\
840 \\
0 \\
0 \\
0
\end{array}
$$

2788

Early Bronze

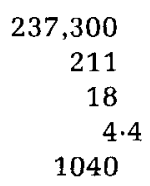

$9 \cdot 3$

$6 \%$

00

127

$$
\begin{gathered}
3 \cdot 4 \\
30 \% \\
23 \% \\
71,100 \\
243 \\
10 \cdot 1 \\
5 \% \\
1 \cdot 6 \\
1 \% \\
\\
2 \cdot 0 \\
0 \cdot 2 \%
\end{gathered}
$$

1,910
1,050
280
0
4,250

TABle 4. Detailed site-signatures for THY 2981, THY 2578 and THY 2788.

After processing the ploughzone tests, we machine-cleared the area to reveal 26 wall-posts and 3 larger roof-support posts in the middle of what is a small, 10x7-m Early Bronze Age house. A firing-pit and a probable cooking-pit were well within the house. Preserved under the ploughzone were 48 flakes, $95 \mathrm{~g}$ of bone, 5 pieces of ceramic, 2 cores and 1 hammerstone. The flakes recovered in situ represent less than $0.02 \%$ of the artefacts estimated at THY 2788 . As indicated there are 237,300 estimated flakes.

An average square metre had $206 \mathrm{~g}$ of flakes. The high point was just north of the house containing $836 \mathrm{~g}$ per sq. $\mathrm{m}$. Based on these figures, almost $1600 \mathrm{~kg}$ of stone were turned into unused flakes at THY 2788. There can be little doubt that the artefacts recovered in the ploughzone are associated with this small Early Bronze Age house.

Although the resolution from ploughzone samples is not fine enough to determine the percentage of flakes in the house, the distribu- 
tion indicates that flaking was going on in and/ or just north of it. In the 42 ploughzone samples from the vicinity of the house there is an average density of 60 flakes per sq. $m$ with a high of 210 flakes per sq. $m$ just north of the house and a low of 6 flakes per sq. $m$ just west of the house. I estimate the presence of 165,500 flakes immediately above the house. The other 10 ploughzone samples show a distinct falloff away from the house.

Have the 72,000 flakes well outside the house been spread out by the plough, or was there a substantial lithic activity outside the house? If the entire 337,500 flakes were originally in the 2500 sq. m surrounding the house, the site has increased in size approximately 5 times. Using the random-walk simulation of Bowers et al. (1983), this would indicate a random walk. of about $1 \mathrm{~m}$ a year per flake in a random direction over 3000 years (assuming no onset of equilibrium). If equilibrium does set in, say after 500 years with a random walk of $2 \mathrm{~m}$, the site should only have been about $100 \mathrm{~m}$ in diameter, and the lithic presence outside the house area indicates a substantial production. One factor pointing towards the latter explanation is that the outside samples average over $1 \mathrm{~g}$ lighter ( $3.1 \mathrm{~g}$ per flake) than the flakes over the house ( $4 \cdot 6 \mathrm{~g}$ per flake). ${ }^{2}$ If flakes had been moved out from a central location, current models of ploughzone movement would predict that these artefacts would tend to be larger (Lewarch \& O'Brien 1981b). On the other hand, natural processes seem to move smaller artefacts farther (Rick 1976), and there appear to be no concentrations of flakes in the area surrounding the house.

For comparative purposes, we assume that all sites were occupied year-round for 10 years (cf. Earle 1994). At THY 2788 the occupants would have produced about 65 flakes per day and discarded a tool every other day. Even though we estimate a large number of flakes at THY 2788, the time devoted to flaking is relatively small. If someone produced 1000 flakes per hour, the lithic scatter would have taken only 240 hours to produce. The total lithic population at THY 2788 would have taken one person working five hours per day 48 days to create.

These estimates do not include retouched flakes. Counts of retouched flakes correlate well with total flake counts $\left(r^{2}=0 \cdot 82\right)$. I estimate

2 Significant to the 0.05 level with 11 degrees of freedom. that there would have been almost 2 retouched flakes per sq. $m$ with a high over the house area of 9 retouched flakes per sq. m. Overall $6 \%$ of the flakes $(13,700)$ were retouched at THY 2788. The average weight of the retouched flakes is $11.9 \mathrm{~g}$.

At THY 2788 we found 64 cores whose distribution is well correlated with the distribution of flakes $\left(r^{2}=0 \cdot 61\right)$. The most diagnostic tool found at THY 2788 was the asymmetrical sickle. The school teacher had found 7 asymmetrical sickles, and we found 8 sickle and sickle fragments in our ploughzone samples. Based on the areas that each ploughzone sample represents, less than 300 sickle and sickle fragments were present at THY 2788. The most numerous recognizable tools were scrapers; we found 31, indicating that about 1050 scrapers were present at the site. Also included in our samples were 5 borers, 3 burins and 2 strike-alights as well as numerous retouched frost flakes. No ceramics were recovered from the ploughzone.

Overall, THY 2788 seems to be an ad hoc production area: tools were made, used, and discarded all in the same location. The numbers of tools, flakes, retouched flakes and cores are all well correlated. Most of the flaking took place in a discrete area in the northern part of the house.

\section{THY 2578 in Vang Parish}

The Thisted Museum investigated THY 2578 in conjunction with the expansion of a gravel quarry. Although museum inspectors found only a few artefacts on the surface (a sickle, a borer and 3 scrapers), they suspected that there might be a settlement and cleared much of the ploughzone with a backhoe. They exposed the postholes of multiple houses. From the post-hole configuration (FIGURE 8), the Thisted Museum dated the houses to the end of the Late Neolithic (Ethelberg 1986; 1991) or possibly the very early Bronze Age. The sub-surface matched the surface in its dearth of artefacts. To increase the artefact count, we laid out seven ploughzone tests around the area already cleared.

The area sampled $(40 \times 40 \mathrm{~m})$ is only slightly larger than the area intensively sampled at THY 2788. Assuming all these flakes were on the surface, the average density would have been 15 flakes per sq. $m$ with a high of 18 over the house area. I estimate there are 25,000 flakes 
and 1600 tools present at the site. The average weight of whole flakes is $3.4 \mathrm{~g}$, and therefore approximately $30 \mathrm{~kg}$ of stone were turned into unretouched flakes.

Retouched flake counts correlate with total flake counts $\left(r^{2}=0.69\right)$, and the average density of retouched flakes is very high (3.1 retouched flakes per sq. $m$ with a high of $4 \cdot 5$ ). The percentage of retouched flakes (19\% from an estimated total of 4700 retouched flakes) is substantially higher at THY 2578 than at THY 2788. The average weight, however, was lower (6 g). The percentage of broken flakes is substantially higher than at THY 2788 with almost $45 \%$ of the flakes being broken.

At THY 2578 we found no cores, 2 blades, 2 burins, 2 borers and 3 scrapers. No bifacial tools were found in ploughzone tests, although a small waste dump from sickle production was found in one of the pits. When taken in the aggregate, these flake tools are not well correlated with the number of flakes $\left(r^{2}=0.55\right)$, although the sample size is small. The ratio of flakes to flake tools at $14: 1$ is much lower than at THY 2788 , implying that great numbers of tools were not being produced at THY 2578. The absence of tool production is corroborated by the fact that the high surface density is close to the average surface density (18.75 and 15.25 flakes per sq. $m$ respectively) - implying that there was no central location where lithic production was taking place.

A comparison of these figures with THY 2788 demonstrates the power of the methodology. There are approximately the same number of tools at both sites (1600 estimated tools at THY 2578 vs 1900 tools at THY 2788). However, THY 2788 has ten times the flakes, an order of magnitude difference. Three variables determine the total number of flakes at a site: the number of people who made flakes, the length of time they made flakes, and the rate at which they made flakes. The first two variables - people and time - indicate the total amount of use at the site; the third, rate, tells us about the intensity of production at the site. Differences in artefact density over the landscape are assumed to correspond with differences in use (Foley 1981a). Differences of an order of magnitude imply a substantial change in settlement pattern, at the extremes occupied either ten times as long or by ten times the number of people. A substantial change in settlement pattern that could account for an order of magnitude difference is unlikely, given that there are approximately the same number of tools at both sites. A more palatable explanation is a slight change in the intensity of lithic production. Assuming that THY 2788 and 2578 were both occupied for 10 years, the production rate at THY 2788 would have been just over 65 flakes per day, at THY 2578 only $6 \cdot 6$ flakes per day. This difference indicates that people at THY 2788 spent five minutes more per day making flakes. This difference in ratios and intensity implies that THY 2578 may have imported stone tools.

Overall, THY 2578 has few flakes. This is not because of an absence of locally available material; this site is over a modern gravel quarry that has an abundance of flint. The locally available flint seems no different from that around THY 2788 (both sites are on glacial moraines). The high percentage of retouched flakes indicates a site where tool use may have been important, but evidently production was on a smaller scale. The high percentage of broken flakes indicates trampling - people were walking in areas of (albeit limited) lithic production. This would not be the kind of assemblage characteristic of any workshop. Flint-knapping on a large scale was not conducted universally at all household sites. However, tool use at THY 2788 and THY 2578 is relatively similar.

\section{THY 2981 in Heltborg parish}

THY 2981 was first registered by the parish survey of 1863 as a knoll where part of a stone axe had been found. In $1915 \mathrm{H}$. Kjær, with the Archaeological Survey, found two pieces of axe around a 'mound' (SB 12) that he assumed must have been higher in the past. We investigated the region as part of a broad survey of Heltborg in 1993 (Bech et al. in press). The field surrounding the 'knoll' was almost completely devoid of flint, and yielded no artefacts. During survey we found 13 scrapers, 3 cores, 6 blades, an axe, a borer and a knife.

In the summer of 1993 we put in 37 ploughzone tests. First we used the offset- 3 pattern. Then we put in the 2 secondary samples per block in the area of dense concentration, and single ploughzone samples in blocks on the outskirts to demonstrate fall-off. Finally we placed a few more samples where we believed the highest concentration to be. While the backhoe was there the last time, we made a 


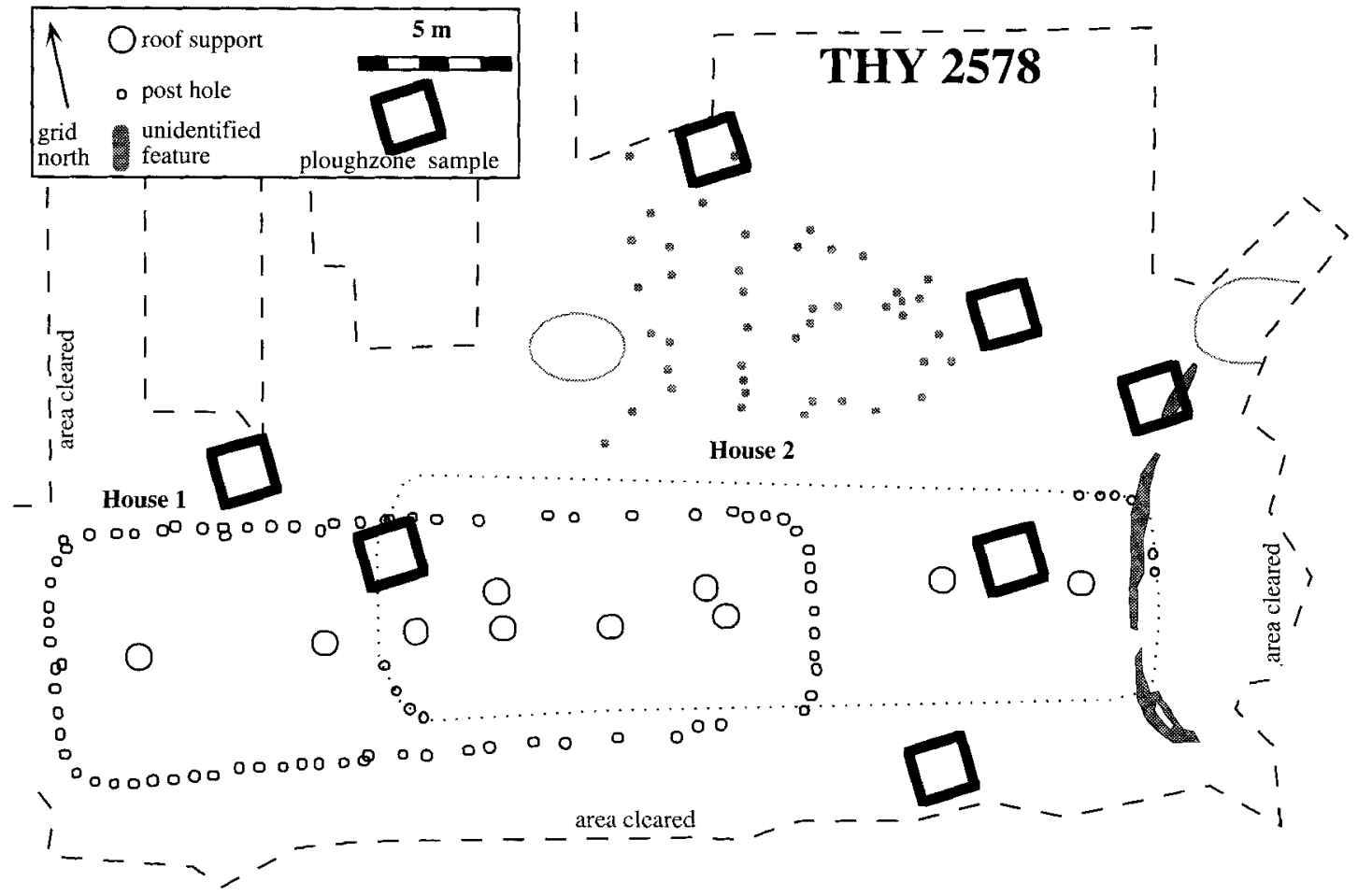

FIGURE 8. Distribution of post-holes and ploughzone samples at THY 2578.

few scrapes to determine if there were any preserved features; one deep pit was found that contained some badly deteriorated pottery and a few flakes, but no diagnostic flint artefacts.

The ploughzone tests revealed an average surface density of 39 flakes per sq. $m$ with a high of 118. Unlike THY 2788, we found two locations of high density (FIGURE 9). I estimate about 666,000 flakes were present at THY 2981. The average weight of whole flakes at THY 2981 is $6.7 \mathrm{~g}$. Over $1700 \mathrm{~kg}$ of stone was turned into unused flakes.

I estimate that over $11 \%$ of the flakes were retouched (about 76,500 flakes). The average weight of a retouched flake at THY 2981 is about $10 \mathrm{~g}$; by weight, over $20 \%$ of the flakes are retouched. The retouched flakes in ploughzone samples are correlated with the number of whole flakes but the relationship is weaker than in the above two examples $\left(r^{2}=0 \cdot 62\right)$. The surface density comes out to an average of $3 \cdot 2$ retouched flakes per sq. $\mathrm{m}$ over the area ploughzone-tested, with a high of 8.25 flakes per sq. $\mathrm{m}$.

What percentage of flakes at THY 2981 are the result of axe production? The weight of the flakes is remarkably consistent with Hansen \& Madsen's (1983) experiments, considering that we do not get the small flakes they recorded. They found an average weight of $5.5 \mathrm{~g}$ per axe flake, but up to $38 \%$ of their recovered flakes could have passed though our screen. With a finer mesh, the $5.9 \mathrm{~g} /$ flake we found would probably drop to a comparable figure. Were all 666,000 flakes estimated at THY 2981 the result of axe production, 550 axes could have been produced. ${ }^{3}$ We found 10 fragments of polished axes ( 4 from four-sided polished axes, usually associated with the Early Neolithic). It is hard to estimate the total number of axes from axe fragments, especially when the density of axe fragments is low. Our inaccurate estimates point to the order of 3500 polished-axe fragments. If each axe was split into 10 fragments with visible polish, we arrive at another estimate, based solely on axe fragments, of 350 . If most of the flakes recovered at THY 2981 were from axe

3 Hansen \& Madsen (1983: 52) produced five axes, ready for polishing, from five nodules and created about almost 6000 flakes larger than $1 \mathrm{~cm}$. An average axe should be represented by 1200 flakes larger than $1 \mathrm{~cm}$. 
manufacture, the other estimated 26,000 tools could have been by-products of axe manufacture (Hansen \& Madsen 1983).

Our glimpse of the lithic manufacture at three sites as viewed from the ploughzone demonstrates that prehistoric lithic economy is varied. THY 2788 looks like a site of ad hoc production where flakes, tools and cores are all closely correlated. THY 2578 looks like a consumer site with a low ratio of flakes to tools and a high percentage of retouched and broken flakes. THY 2981 seems to be a site where a fair amount of production took place.

These three sites are examples of the 17 sites we have ploughzone tested (TABLE 3). Based on our total sample of sites we can begin to draw some preliminary conclusions.

\section{Inter-site lithic production}

Over the Danish landscape, especially in Thy, it is said a few flakes can be found on almost every farmer's field. Previously, this low level of lithic production has been characterized as background noise (Gallant 1986). In surface surveys there has been much written of the importance of background noise in understanding regional lithic production (Crowther et al. 1985; Read 1985: 42; 1989; Wandsnider \& Camilli 1992), a concept taken further with offsite archaeology (Ebert 1992; Foley 1981a; 1981b; Rossignol \& Wandsnider 1992; Shott 1995; Thomas 1975). Where does most of the lithic production take place in Thy: at concentrated sites or dispersed across the landscape? If most of the lithic ргоduction took place at sites, are they relatively equal or do a few large sites account for most of the flakes?

In order to quantify background noise, we did a series of shovel tests. These small extensive tests put our intensive ploughzone tests into perspective Our preliminary results suggest that while background noise may be the remnants of the majority of areas used in prehistory and contain substantial lithic remains, they constitute a small proportion of total lithic production. Most lithic production took place at a few sites during the Neolithic and Early Bronze Age.

\section{Shovel testing}

In order to identify large dense lithic scatters in pasture and woodlands, TAP instituted a shovel-testing programme (Kintigh 1988; Krakker et al. 1983; Lightfoot 1986; 1989; Lovis 1976;
McManamon 1984; Nance \& Ball 1986; 1989; Shott 1989; Sydoriak 1985). We also shoveltested large tracts of ploughed area that were fieldwalked to estimate low-level lithic production, quantifying those few flakes found on almost every field (Wobst 1983).

A site that has been ploughed must have at least 20,000 flakes in a hectare to be discovered during fieldwalking. These flakes spread over a hectare have an upper limit of 800 artefacts recovered in a total surface pick-up of a $50 \times 50 \mathrm{~m}$ area $(16 \%$ of the artefacts visible on the surface (Shott 1995)). The lower limit is 15 if $0.3 \%$ of the artefacts are visible on the surface (Clark \& Schofield 1991: 95). Our preliminary results suggest that $0 \cdot 5 \%$ of the total flakes present are recovered on the surface at Early Neolithic sites and a lesser percentage at Late Neolithic/Early Bronze sites. For convenience I call areas with 20,000 flakes activity areas in contrast to sites. Do these activity areas account for a majority of lithic production?

Shovel-test samples are too small (20 l of screened soil) to take advantage of the homogeneity; therefore estimating the number of flakes in the region around a single sample would be unreliable. Instead, the samples must be understood in the aggregate (Wobst 1995). The actual method involved filling a $20-1$ bucket with soil taken from the centre of a $50 \times 50-\mathrm{m}$ block. The soil is then screened and the artefacts (primarily flakes) counted.

In Heltborg (a parish close to the average in stray finds recorded in the Thisted Museum), we did a series of 92 shovel tests over $0.25 \mathrm{~km}$. These yielded an average of 0.30 flakes per 20 litres. This small survey covered two Early Neolithic sites that we ploughzone-sampled (THY 2981 (see above) and THY 3401) that accounted for 21 of the shovel tests. The 71 'off-site' tests have an average of 0.22 flakes per 20 litres. Assuming that this density is representative of the region, 'off-site activity' is responsible for 586,000 flakes. The two sites shovel-tested had an average of 0.57 flakes per 20 litres and by this same reasoning should have 450,000 flakes. Like surface survey, shovel tests yield inaccurate estimates for the densities at sites: THY 2981 and 3401 account for 807,000 flakes.

The 586,000 'off- site' flakes indicate the presence of 30 activity areas, a ratio of 15 activity areas to 1 site in this area. In this small sam- 


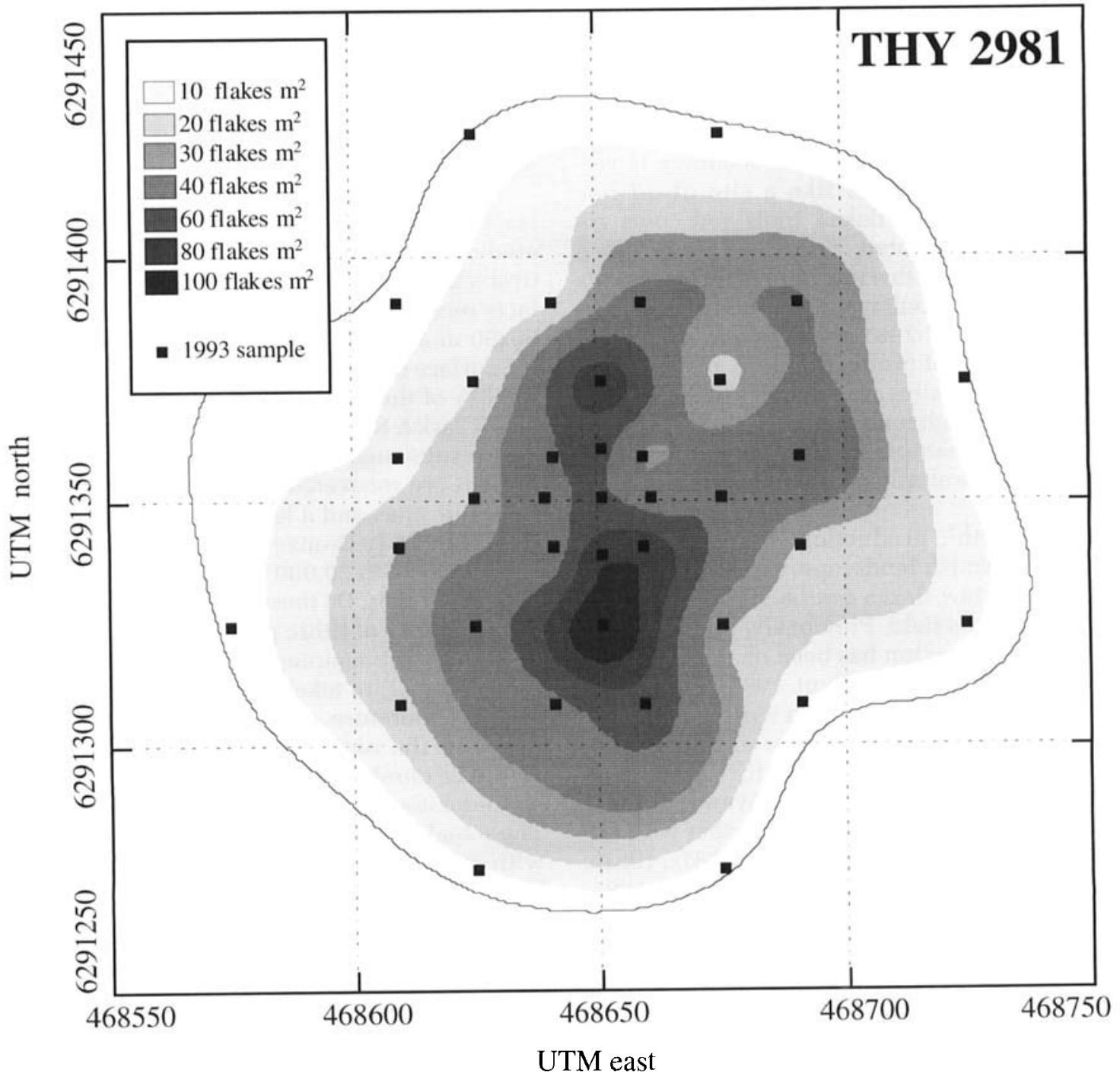

FIGURE 9. Flake distribution at THY 2981 (Early Neolithic).

ple, it would appear that activity areas account for $95 \%$ of the areas where lithic production took place but probably less than $50 \%$ of the lithic production.

\section{Lithic production at sites}

If sites represent locations where a majority of the lithic production took place, how uniform is the production between sites? The three casestudies presented above demonstrate that the amount of lithic production varies tremendously. Is this variation so much so that a few big sites produce most of the flakes?
Assuming that the sites ploughzone-tested represent the spectrum of flake and tool populations at sites (TABLE 4), I used a K-means cluster analysis with tools and flakes estimated at sites. Two clusters proved the only solution that included THY 3463 with other sites in a cluster. The division is highly significant with 15 degrees of freedom. The top cluster has an average of 991,000 flakes, and the bottom an average of 188,000 flakes.

We find the proportion of total lithic production resulting from a given site cluster $\left(t_{1}\right)$ by using the equation: 

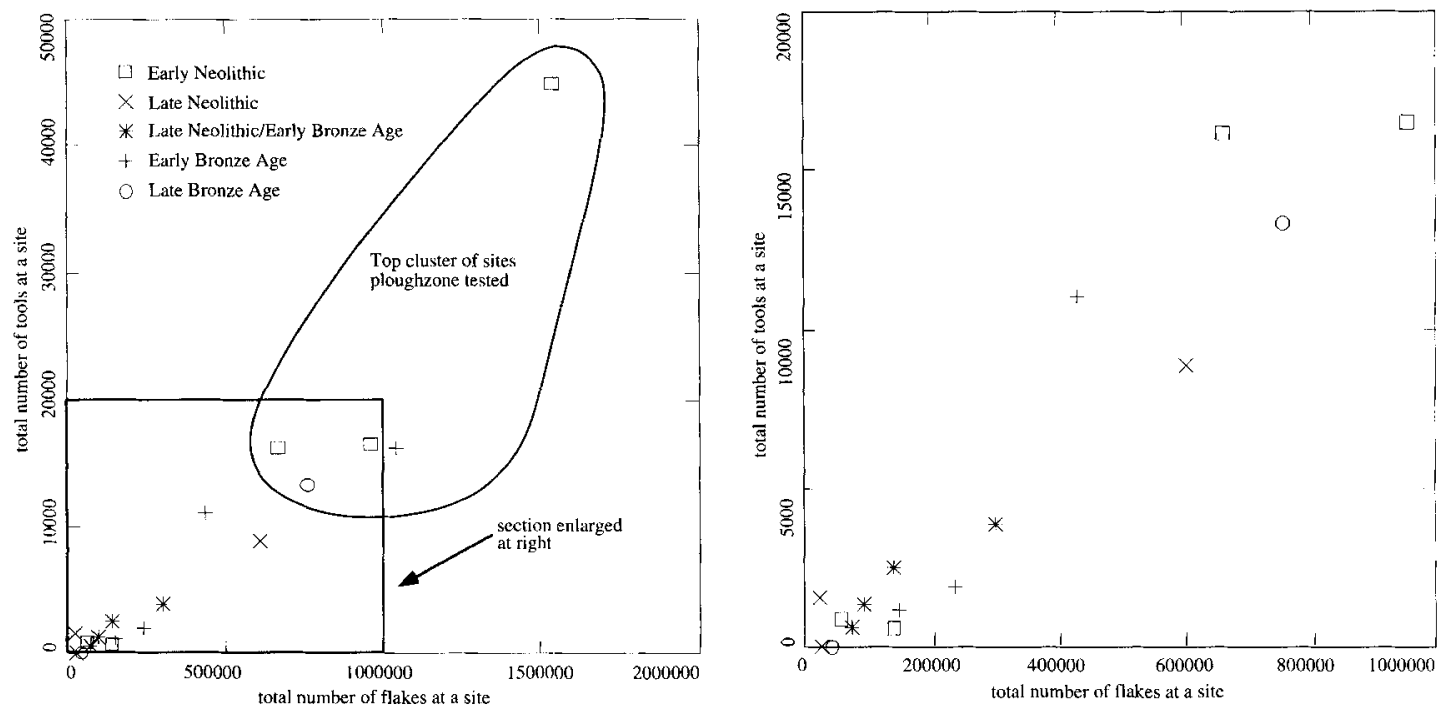

FIGURE 10. relationship between the estimated total number of flakes and the estimated total number of tools at all ploughzone tested sites.

$$
\frac{P_{1} \bar{A}_{1}}{\sum_{i=1}^{\mathrm{n}} P_{i} \bar{A}_{i}}=t_{1}
$$

where $P$ is the portion of sites represented by a given cluster, $\bar{A}$ is the average number of flakes in a given cluster, and $t$ is the proportion of all flakes that the cluster is responsible for producing. This equation is in contrast to the ranksize approach of Zvelebil et al. (1992; see also Foley 1981c). The rank-size picture is one of ubiquity so that each area is treated equally. The result is a ratio of home bases to off-site activity areas. Using Zvelebil et al.'s data with the above equation produces results similar to the ones presented below. I choose to emphasize the relative importance, based on lithic production, of each area rather than its presence.

The bottom cluster of sites ploughzone-tested ( $71 \%$ of sites) accounts for $31 \%$ of the flakes (FIGURE 10). The top cluster (29\% of the sites) accounts for $69 \%$ of the flakes, and the top $50 \%$ of sites (by flakes) for almost $89 \%$ of the flakes

If we assume, from the shovel-testing data, that the sites ploughzone-tested are only $5 \%$ of the areas where lithic production took place, then those ploughzone-tested sites are responsible for the majority of the lithics. The sites ploughzone-tested have an average of 424,000 flakes. Using the equation above, and assum-

ing the activity areas shovel-tested ( $95 \%$ of areas) represent 20,000 flakes each, we find that the ploughzone-tested sites account for over $52 \%$ of the lithic production. The top cluster of sites determined above $(1.5 \%$ of the areas with an average of 991,000 flakes) represents $36 \%$ of total lithic production. The middle cluster $(3.5 \%$ of sites) represents $16 \%$ of lithic production. The small-activity areas (95\% of areas) represent $48 \%$ of lithic production. Thus, throughout the Neolithic and Early Bronze Age, most stone-tool manufacture seems to be concentrated in just a few sites.

\section{Conclusion}

Ploughzone testing is possible, the methodology is powerful, and the results are meaningful. Primarily, this is a methodological paper that examines how to quantify sites that have been ploughed. In presenting this method, I have considered the division of lithic activity. To get at these issues, I have ignored different stages of lithic production and different time-periods, but these issues and others I have ignored can be addressed with a ploughzone methodology. If flakes can be used as a proxy for other economic activities, the results imply that most economic activity took place at a few sites. If we are going to understand the majority of sites in heavily ploughed areas, we must start an intensive ploughzone-sampling programme. 
It is feasible accurately to quantify sites that have been ploughed - to circumvent the ploughzone paradox and 'excavate' those disturbed sites. Artefacts in the ploughzone have not been moved to such an extent as to render ploughed sites unrecognizable. The conventional approach of surface collecting does not reveal the true nature of the site. The sample is too small, and the results are biased. The only way to quantify sites that have been ploughed is to excavate chunks of ploughzone and screen to recover artefacts.

The ploughzone method is powerful. In some ways, ploughing is a blessing in disguise; destroying the stratigraphy and sweeping away the information it contains, the plough opens the site remnants to this 'quick and dirty' approach. The strategy and equipment make ploughzone testing an economical methodology whereby sites can be investigated quickly and cheaply. The resultant site signature, the sum total of all the (lithic) activity preserved, contains a tremendous amount of information as the three case-studies demonstrate.

The results are meaningful. More than simply qualifying sites as lithic production or consumption sites, the methodology allows us to quantify sites and infer the importance of production. Production seems to be concentrated

\section{References}

ABBOTT, D. 1985. Unbiased estimates of feature frequencies with computer simulation, American Archaeology 5: 4-11.

AHLER, S. 1986. The Knife River Flint Quarries: excavations at site 32DU508. Bismarck (ND): State Historical Society of North Dakota.

1989. Mass analysis of flaking debris: studying the forest rather than the tree, in D. Henry \& G. Odell (ed.), Alternative approaches to lithic analysis: 85-118. Washington (DC): American Anthropological Association.

ALLEN, M.J. 1991. Analysing the landscape: a geographical approach to archaeological problems, in Schofield (ed.): 39-57.

Ammerman, A.J. 1981. Surveys and archaeological research, Annual Review of Anthropology 10: 63-88.

1985. Plow-zone experiments in Calabria, Italy, Journal of Field Archaeology 12: 33-40.

APLRLO, P. 1994. Scraping the bottom of the barrel. MA thesis, Department of Anthronology, University of California, Los Angeles.

AScH, D. 1975. On sample size problems and the uses of nonprobabilistic sampling, in Mueller (ed.): 170-91.

BAGGE JOHANSEN, M. 1987. Brachiopods from the MaastrichtianDanian boundary sequence at Nye Klov, Jylland, Denmark. Oslo: Universitetsforlaget.

BAKER, C. 1978. The size effect: an explanation of variability in surface artifact assemblage content, American Antiquity 43: $734-40$

BAKER, C. \& M. SCHIFFER. 1975. Archaeological evidence for the size effect, in C. Baker (ed.), Arkansas Eastman Archaeological Project: 117-22. Fayetteville (AS): Arkansas Archaeological Survey.

BAMFORTH, D. 1986. Technological efficiency and tool curation, American Antiquity 51: 38-50. in a very few sites. In the Neolithic and Early Bronze Age, over $50 \%$ of the production seems to be concentrated in well under $25 \%$ of the sites.

In contrast to the many aspects of prehistory that cannot be quantified, stone-tool production, exchange and use can be quantified. Stone-tool production is the single richest preserved archaeological resource, and most of the evidence is in large tracts of ploughed land.

Acknowledgements. This research was funded by the $\mathrm{Na}$ tional Science Foundation Grant \# SBR-9207082, the Danish Fulbright Commission, the Anthropology Department at UCLA, and the UCLA Friends of Archaeology. This work could not have happened without the Thisted Museum, especially Jens-Henrik Bech, Louise Olsen and the director, Jette Kjær; the Danish Forest and Nature Agency, particularly Kristian Kristiansen; and the British, Danish and American TAP teams, especially P. Aperlo, L. Barrett, B. Daniels, J. Humphreys, B. Jones, R. Mansfield, M. Rowlands, N. Thorpe, H. Starr and J. Westphal. V. Triffonof set the ploughzone record by helping me screen 21 samples in one day. Scott Pletka was invaluable in screening and size sorting. Mr Mikkelsen at the Tourp Smed, Moss, constructed The Machine and made many useful additions to the original design, especially the shock absorbers. Ray Dillman drew the diagram of The Machine. I wish to thank J. Arnold, A. Cody, L. DeMarrais, G. Eby, K. Kelly, J.L. RosenthaI, M. Shott and the anonymous reviewers for their help and constructive suggestions. Pattie Rechtman did an outstanding job editing the first version. Tim Earle gave me the opportunity to dig and Jens Kristensen did the digging.

BARKER, G. 1975. To sieve or not to sieve, Antiquity 49: 61-3. BECH, J.H. et al. In press. The Thy Archaeological Project: preliminary report, Journal of Danish Archaeology 12.

BINFORD, L. 1982. The archaeology of place, Journal of Anthropological Archaeology 1: 5-31.

BOWERS, P., R. BONNICHSEN \& D. HOCH. 1983. Flake dispersal experiments: noncultural transformations to the archaeological record, Americon Antiquity 48: 553-72.

BRADLEY, R. 1987. A field method for investigating the spatial structure of lithic scatters, in Brown \& Edmonds (ed.): 39-47.

BRown, A.G. \& M.R. EDMONDs (ed.). 1987. Lithic analysis and later British prehistory: some problems and approaches. Oxford: British Archaeological Reports. British series 162.

CARR, C. 1982. Handbook on soil resistivity surveying: interpretation of data from earthen archaeological sites. Evanston (IL): Center for American Archaeology.

CHerry, J. 1984. Common sense in Mediterranean survey, Journal of Field Archaeology 11: 117-20.

Christenson, A.L. 1982. Maximizing clarity in economic terminology, American Antiquity 47: 419-26.

ClARK, R.H. \& A.J. SCHOFIELD. 1991. By experiment and calibration: an integrated approach to archaeology of the ploughsoil, in Schofield (ed.): 93-105.

ClARKE, D.L. 1977. Spatial archaeology. New York (NY): Academic Press.

ClARKE, D.V. 1979. Excavation and volunteers: a cautionary tale, World Archaeology 77: 172-6.

COTTERLLL, B. \& J. KAMMINGA. 1979. The mechanics of flaking, in B. Hayden (ed.), Lithic use-wear analysis: 97-112. New York (NY): Academic Press.

1987. The formation of flakes, American Antiquity 52: 675-708. 
CROWTHER, D. 1983. Old land surfaces and modern ploughsoil: implications of recent work at Maxey, Scottish Archaeological Review 2: 31-44.

Crowther, D., C. French \& F. PrYor. 1985. Approaching the Fens the flexible way, in Haselgrove et al. (ed.): $59-76$.

DANCEY, W.S. 1981. Archaeological field methods: an introduction. Minneapolis (MN): Burgess.

DRISKELL, B. 1986. The chipped stone tool production/use cycle. Oxford: British Archaeological Reports. International series 305.

DUNNELL, R.C. 1990. Artefact size and lateral displacement under tillage - comments on the Odell and Cowan experiment, American Antiquity 55: 292-4.

1992. The notion site, in Rossignol \& Wandsnider (ed.): 21-41.

DUNNFLL, R.C. \& W.S. DANCEY. 1983. The siteless survey: a regional scale data collection strategy, Advances in archaeological method and theory 6: 267-87.

DUNNELL, R.C. \& I.F. SIMEK. 1995. Artifact size and plowzone processes, Journal of Field Archaeology 22: 305-19.

EARLE, T.K. 1994. Studying prehistoric architecture in Danish prehistory. Paper presented at the annual meetings of the American Anthropological Association, Atlanta (GA).

EBERT, J.I. 1992. Distributional archaeology. Albuquerque (NM): University of New Mexico Press.

ENGLISH HERJTAGE. 1995. Planning for the past 1. London: English Heritage.

ENSOR, H.B. \& E. ROEMER. 1989. Comments on Sullivan and Rozen's debitage analysis and archaeological interpretation, American Antiquity 54: 175-8.

ETHELBERG, P. 1986. Early Bronze Age house at Højgård, southern Jutland, Journal of Danish Archaeology 5: 152-67.

1991. Two more house groups with three-aisled long-houses from the Early Bronze Age at Højgård, south Jutland, Journal of Danish Archaeology 10: 136-55.

Fischer, A., B. GrønNow, J.H. Jønsson, F.O. Nielsen \& C. PETEREN. 1979. Stenalder-eksperimenter in Lijere. Copenhagen: Nationalmuseet.

FISH, P. 1979. The interpretive potential of Mousterian debitage. Tempe (AZ): Arizona State University.

1981. Beyond tools: Middle Paleolithic debitage analysis and cultural inference, Journal of Anthropological Research 37: 374-86.

FLENNIKEN, J.J. \& J. HAGGERTY. 1979. Trampling as an agency in the formation of edge damage: a experiment in lithic technology, Northwest Anthropological Research Notes 13: 208-14.

FOLEY, R. 1981a. Off-site archaeology and human adaptation in eastern Africa. Oxford: British Archaeological Reports. International series S97.

1981b. Off-site archaeology: an alternative approach for the short-sited, in I. Hodder, G. Isaac \& N. Hammond (ed.), Pattern of the past: 157-82. Cambridge: Cambridge University Press.

1981c. A model of regional archaeological structures, Proceedings of the Prehistoric Society 47: 1-17.

FORD, S. 1987. Flint scatters and prehistoric settlement patterns in south Oxfordshire and east Berkshire, in Brown \& Edmonds (ed.): 101-35.

FRINK, D.S. 1984. Artifact behavior within the plowzone, Journal of Field Archaeology 11: 356-63.

GAFFNEY, C., V. GAFFNEY \& M. TINGLE. 1985. Settlement, economy of behaviour? Micro-regional land use models and the interpretation of surface artefact patterns, in Haselgrove et al. (ed.): 95-107. Sheffield: University of Sheffield.

GALlaNT, T.W. 1986. 'Background noise' and site definition: a contribution to survey methodology, Journal of Field Archaeology 13: 403-18.

GARDiner, J. 1987. Rocks and risk, in Brown \& Edmonds (ed.): $75-89$.

GingeLl, C. \& R.T. SCHAdLA-HALl. 1980. Excavations at Bishops Cannings Down, 1976, in Hinchiffe \& Schadla-Hall (ed.): 109-13.

HAGGETT, P. 1965. Locational analysis in human geography. London: Edward Arnold.
HANSEN, P.V. \& B. MADSEN. 1983. Flint axe manufacture in the Neolithic: experiments with grinding and polishing of thin-butted flint axes, Journal of Danish Archoeology 2: $43-57$.

HASELGROVE, C. 1985. Inference from ploughsoil artefact samples, in Haselgrove et al. (ed.): 7-30.

Haselgrove, C., M. Millett \& I. Smith (ed.). 1985a. Archaeology from the ploughsoil: studies in the collection and interpretation of field survey data. Sheffield: University of Sheffield.

1985b. Introduction, in Haselgrove et al. (ed.): 1-6.

HinchlifFE, J. \& R.T. SCHADLA-HALl (ed.). 1980. The past under the plough. London: Department of the Environment.

HOFFMAN, C. 1982. Plow zones and predictability: sesquinary context in New England prehistoric sites, North American Archaeologist 3: 287-309.

HoLM, J. 1991. Settlements of the Hamburgian and Federmesser cultures at Slotseng, south Jutland, Journal of Danish Archaeology 10: 7-19.

HOUSE, J. \& M. SCHIFFER. 1975. The Cache River Archaeological Project: an experiment in contract archaeology, Arkansas Archaeological Survey, research series 8: 37-53.

HUGHES, P.J. \& R.J. LAMPERT. 1979. Occupational disturbance and types of archeological deposit, Journal of Archaeological Science 4: 135-40.

KinTIGH, K.W. 1988. The effectiveness of subsurface testing: a simulation approach, American Antiquity 53: 687-707.

KISH, L. 1967. Survey sampling. New York (NY): John Wiley.

KNOERI, J.J. 1976. Methodological approaches to site examination at Loder cornfield, in M. Weide (ed.), I-88 archeological project: 1975 summer season. Manuscript on file in the Public Archaeology Facility at SUNY-Binghamton (NY).

KNOERL, J. \& N. VERSAGGI. 1984. Plow zone sites: research strategies and management policy, American Archaeology 4: $76-80$.

KOUWENHOVEN, J. \& R. TERPSTRA. 1979. Sorting action of tines and tine-like tools in the field, Journal of Agricultural Engineering Research 24: 95-113.

KRAKKER, J., M. ShotT \& P. WELCH. 1983. Design and evaluation of shovel-test sampling in regional archaeological survey, Journal of Field Archaeology 10: 469-80.

KRISTENSEN, I.K. 1989. Storgård IV, Journal of Danish Archaeology 8: 72-87.

KRISTIANSEN, K. (ed.). 1985. Archaeological formation processes. the representativity of archaeological remains from Danish prehistory. Copenhagen: Nationalmuseet.

LAMBRICK, G. 1977. Archaeology and agriculture: a survey of modern cultivation methods and the problems of assessing plough damage to archaeological sites. London: Council for British Archaeology and Oxfordshire Archaeological Unit. Survey 4.

LAWSON, A.J. 1980. Ploughing on archaeological sites in Norfolk: some observations, in Hinchliffe \& Schadla-Hall (ed.): 74-7.

LEWARCH, D.E. \& M.J. O'BRIEN. 1981a. The expanding role of surface assemblages in archaeological research, Advances in Archaeological Method and Theory 4: 297-342.

$1981 \mathrm{~b}$. Effects of short term tillage on aggregate provenience surface pattern, in O'Brien \& Lewarch (ed.): 7-49.

LIGHTFOOT, K. 1986. Regional surveys in the Eastern United States: the strengths and waaknesses of implementing subsurface prograns, American Antiquity 51: 484-504. 1989. A defense of shovel-test sampling: a reply to Shott, American Antiquity 54: 413-16.

LOVIs, W. 1976. Quarter sections and forests: an example of probability sampling in the northeastern woodlands, American Antiquity 41: 364-72.

MALLOUF, R.J. 1982. An analysis of plow-damaged chert artifacts: the Broken Creek cache (41HI86), Journal of Field Archaeology 9: 79-98.

MCManamon, F. 1984. Discovering sites unseen, Advances in Archaeological Method and Theory 7: 223-92.

MiLis, N. 1985. Sample bias, regional analysis and fieldwalking in British archaeology, in Haselgrove et al. (ed.): 39-47.

MUELLER, J. (ed.). 1975. Sampling in archaeology. Tucson (AZ) University of Arizona Press. 
MurRaY, P. 1980. Discard location: the ethnographic data, American Antiquity 45: 490-502.

NANCE, J. 1983. Regional sampling in archaeological survey: the statistical perspective, Advances in Archaeological Method and Theory 6: 289-356.

1988. Reliability, validity and quantitative methods in archaeology, in M. Aldenderfer (ed.), Quantitative research in archaeology: 244-93. Beverly Hills (CA): Sage Publications.

NANCE, J. \& B. BALL. 1981. The influences of sampling unit size on statistical estimates in archaeological site sampling, in O'Brien \& Lewarch (ed.): 51-70.

NARTOV, P.S. 1984. Movement of soil masses by the working of surfaces of spherical disks. New Delhi: Amerind Publishing.

NIELSEN, L.E. 1993. Proveniensundersøgelser af flint i Europæisk archæologi: metoder og Muligheder-og Muligheder i Danmark. MA thesis, Institut for Forhistorisk Arkæologi, Aarhus University.

O'BREN, M. \& D. LEWARCH (ed.). 1981. Plowzone archaeology: contributions to theory and technique. Nashville (TN): Vanderbilt University.

ODELL, G.H. \& F. COWAN. 1987. Estimating tillage effects on artifact distributions, American Antiquity 52: 456-84.

PAYNE, S. 1972. Partial recovery and sample bias: the results of some sieving experiments, in E. Higgs (ed.), Papers in economic prehistory: 49-64. Cambridge: Cambridge University Press.

PETERSEN, P.V. 1993. Flint: fra Danmarks oldtid. Copenhagen: Høst \& Søn.

PLOG, S. \& M. HEGMON. 1993. The sample size-richness relation: the relevance of research questions, sampling strategies and behavioral variation, American Antiquity 58: 489-96.

PLOG, S., F. PLOG \& K. WAIT. 1978. Decision making in modern surveys, Advances in Archaeological Method and Theory 1: 415-17. New York (NY): Academic Press.

PRENTISS, W. \& E. ROMANSKI. 1989. Experimental evaluation of Sullivan \& Rozen's debitage typology, in D. Amick \& R. Mauldin (ed.), Experiments in lithic technology: 8999. Oxford: British Archaeological Reports. International series S328.

READ, D. 1985. Pattern recognition as a paradigm for data analysis, American Archaeology 5: 41-7.

1989. Statistical methods and reasoning in archaeological Research: a review of paraxis and promise, Journal of Quantitative Anthropology 1: 5-78.

REDMAN, C. \& P.J. WATSON. 1970. Systematic intensive surface collection, American Antiquity 35: 279-91.

REYNOLDS, P.J. 1982. The ploughzone, in Festschrift zum 100 jahrigen Bestehen der Abteilung für Vorgeschichte: 31540. Nürnberg: Naturhistorische Gesellschaft.

REYNOLDS, P.J. \& R.T. SCHADLA-HALL. 1980. Measurement of plough damage and the effects of ploughing on archaeological material, in Hinchliffe \& Schadla-Hall (ed.): 11422 .

RICHARDS, J. 1985. Scouring the surface: approaches to the ploughzone in the Stonehenge environs, Archaeological Review from Cambridge 4: 27-42.

Rick, I.W. 1976. Downslope movement and archaeological intrasite spatial analysis, American Antiquity 41: 13344.

RIORDAN, R. 1982. The controlled surface collection of a multicomponent site in Southwestern Ohio: a replication experiment, Mid-Continental Journal of Archaeology $7: 45-59$.

ROPER, D. 1976. Lateral displacement of artifacts due to plowing, American Antiquity 41: 372-5.

ROSSIGNOL, J. \& L. WANDSNIDER (ed.). 1992. Space, time and archaeological landscapes. New York (NY): Plenum Press.

SCHIFFER, M.B., A.P. SULLIVAN \& T.C. KLINGER. 1978. The design of archaeological surveys, World Archaeology 10: 6-8.

SCHOFIELD, A.J. (ed.). 1991a. Interpreting artefact scatters: contributions to ploughzone archaeology. Oxford: Oxbow. 1991b. Interpreting artefact scatters: an introduction, in Schofield (ed.): 3-8.

SHENNAN, S.J. 1985. Experiments in the collection and analysis of archaeological survey data: the East Hampshire Survey. Sheffield: Sheffield University Press.

Sнотт, M. 1989. Shovel-test sampling in archaeological survey: comments on Nance \& Ball, and Lightfoot, American Antiquity 54: 369-404.

1992. Commerce or service: models of practice in archaeology, in L. Wandsnider (ed.), Quandaries and quests: visions of archaeology's future: 9-24. Carbondale (IL): Southern Illinois University Press.

1994. Size and form in the analysis of flake debris: review and recent approaches, Journal of Archaeological Method and Theory 1: 69-110.

1995. Reliability of archaeological records on cultivated surfaces: a Michigan case study, Journol of Field Archaeology 22: 475-90.

STAHLE, D. \& J. DUNN. 1982. An analysis and application of the size distribution of waste flakes from the manufacture of bifacial stone tools, World Archaeology 14: 84-97.

Stockтon, E.D. 1973. Shaw's Creek Shelter; human displacement of artifacts and its significance, Mankind 9: 11217.

SULLIVAN, A. \& K. ROZEN. 1985. Debitage analysis and archaeological interpretation, American Antiquity 50: 755-99.

SYDORIAK, K. 1985. Pattern recognition at the intra-site level using trend surface analysis, American Archaeology 5: 59-63.

TALMAGE, V. \& O. CHESTER. 1977. The importance of small surface, and disturbed sites as a sources of significant archaeological data. Washington (DC): Office of Archaeology and Historic Preservation, National Park Service.

Thomas, D.H. 1975. Nonsite sampling in archaeology: up a creek without a site?, in Mueller (ed.): 62-3.

Tringham, R., G. COOPER, G. ODELl, B. VOYTEK \& A. WhitMan. 1974. Experimentation in the formation of edge damage: a new approach to lithic analysis, Journal of Field Ar. chaeology 1: 171-96.

TRLjBowitz, N. 1978. The persistence of settlement pattern in a cultivated field, in W. Engelbrecht \& D. Grayson (ed.), Essays in Northeastern anthropology in memory of Marian E. White: 41-66. Rhindge (NH): Department of Anthropology, Franklin Pierce College. Occasional publications in Northeastern Anthropology 5.

WANDSNIDER, L. \& E. CAMILLI. 1992. The character of surface archaeological deposits and its influence on survey accuracy, Journal of Field Archaeology 19: 169-88.

WARREN, R.E. 1982. Prehistoric settlement patterns, in M. O'Brien \& D. Lewarch (ed.), The Cannon River Human Ecology Project: an archaeological study of cultural adaptations in the Southern Prairie Peninsula: 337-68. New York (NY): Academic Press.

WoBST, M. 1983. We can't see the forest for the trees: sampling and the shapes of archaeological distributions, in J. Moore \& A. Keene (ed.), Archaeological hammers and theories: 37-85. New York (NY): Academic Press.

WOOD, R. \& D. JOHNSON. 1978. A survey of disturbance processes in archaeological site formation, Advances in Archaeological Method and Theory 1: 315-81.

WOODWARD, P.J. 1978. A problem oriented approach to the recovery of knapped flint debris: a fieldwalking strategy for answering questions posed by site distributions and excavation, in J. Cherry, C. Gamble \& S. Shennan (ed.), Sampling in contemporary British archaeology: 121-7. Oxford: British Archaeological Reports. British series 50.

YELLEN, J.E. 1977. Archaeological approaches to the present: models for reconstructing the past. New York (NY): Academic Press.

YouRsToN, R.M. 1990. Comment on estimating tillage effects on artifact distributions, American Antiquity 55: 54998.

Zvelebil, M., S. GReen \& M. Macklin. 1992. Archaeological landscapes, lithic scatters and human behavior, in Rossignol \& Wandsnider (ed.): 193-226. 


\title{
Appendix: \\ Construction of confidence intervals for the estimated total number of artefacts in a region
}

\author{
DWIGHT W. READ*
}

Assume we have a region, $R$, divided into $m$ subregions each with area, $S_{1}, S_{2}, \ldots, S_{m}$, respectively. Assume that in the $i$ th subregion, $S_{i}$, one quadrat of area $Q_{i}$ is selected and number of artefacts, $n_{i}$, of a specified type, $T$, is found in quadrat $Q_{i}$. Suppose we use the artefact counts, $n_{1}, n_{2}, \ldots, n_{m}$ corresponding to the $m$ quadrats to estimate the total number, $\hat{N}$, of artefacts of type, $T$, in the region, $R$, in the following manner. First, estimate the number, $\hat{N}$, of artefacts of type, $T$, in the $i$ th subregion:

$\hat{N_{i}}=\left(S_{i} / Q_{i}\right)\left(n_{i}\right)$

Next, add across all subregions to obtain the estimated number of artefacts in the region, $R$ :

$\hat{N}=\sum \hat{N}$

We now want to construct a $1-\alpha$ confidence interval (CI) for the estimate, $\hat{N}$, of the total number of artefacts of type $T$ in the region $R$.

To construct a CI for the estimate, $\hat{N}$, we need to model the process by which artefacts are distributed across the region. We assume that in each subregion, $S_{i}$, there are $N_{i}$ artefacts of type $T$ randomly placed throughout the subregion $S_{i}$. We further assume that the quadrat, $Q$, in subregion $S$ is randomly located within that subregion. Under these assumptions we may characterize the number, $n_{i}$, of artefacts of type $T$ in quadrat $Q_{i}$ within the $S_{i}$ subregion as a single observation from a binomial distribution (BD). This claim is justified as follows. Suppose we place the $N_{i}$ artefacts of type $T$ randomly within the subregion, $S_{i}$. For a single, fixed quadrat, $Q_{i}$, in the $S_{i}$ subregion, we may view placement (via random distribution of artefacts in subregion $S_{i}$ ) of an artefact of type $T$ in the quadrat as a Success, otherwise as a Failure (following the unusual nomenclature for a binomial distribution). The probability of a success is given by $P_{i}=Q_{i} / S_{j}$ and the number of trials is given by $N_{i}$. Thus the number of Successes (i.e., the number of artefacts, $n_{i}$, in the quadrat $Q_{i}$ ) will be an observation from a binomial distribution with mean given by:

$\mu_{B D}=N_{i} P_{i}$

and standard deviation given by:

$\sigma_{B D}=\sqrt{N_{i} P_{i}}\left(1-P_{i}\right)$
If $\mu_{B D} \geq 5$ and $N_{i}-\mu_{B D} \geq 5$, then we may approximate the binomial distribution by a normal distribution with mean $\mu_{B D}$ and standard deviation $\sigma_{B D}$. Using this approximation it follows that for the ith subregion, $S_{i}$, a $1-\alpha$ confidence interval for $\mu_{B D}$ based upon the observed number, $n_{i}$, of artefacts found in quadrat $Q_{i}$ is given by:

$n_{i}-\left(z_{a / 2}\right)\left(\sigma_{B D}\right) \leq \mu_{B D}=N_{i} P_{i} \leq n_{i}+\left(z_{a / 2}\right)\left(\sigma_{B D}\right)$

hence a $1-\alpha$ CI for $N_{i}$ is given by:

$\hat{N}_{i}-\left(z_{\alpha / 2}\right)\left(\sigma_{B D} / P_{i}\right) \leq N_{i} \leq \hat{N}_{i}+\left(z_{\alpha / 2}\right)\left(\sigma_{B D} / P_{i}\right)$,

and $\sigma_{\hat{N}}=\sigma_{B D} / P_{i}$

Next, let $X_{i}$ measure the estimated number, $\hat{N}_{i}$ of artefacts in $S_{i}$ based upon the number, $n_{i}$, of artefacts found in a quadrat $Q_{i}$ placed randomly within the subregion, $S_{i}$. Then $X_{i}$ is a random variable whose value is $N_{i}$ for the quadrat $Q_{i}$, and $\sigma_{X}=\sigma_{\hat{N}^{*}}$. We can now extend Equation (5') to a 1- $\alpha$ CI for $\hat{N}$ as follows. Let $X=\Sigma X_{i}$. Then $\sigma_{X}{ }^{2}=\sigma_{X}{ }^{2}+\sigma_{X}{ }^{2}+\ldots+\sigma_{X}{ }^{2}$ under the assumption that the number of artefacts, $n_{i}$, in the $Q_{i}$ quadrat within the subregion, $S_{i}$, is independent of the number of artefacts, $n_{i}$, in the $Q$. quadrat within the subregion, $S_{j}$. From Equation (2) it follows that:

$\hat{N}-\left(z_{a / 2}\right)\left(\sigma_{X}\right) \leq N \leq \hat{N}+\left(z_{a / 2}\right)\left(\sigma_{X}\right)$

We may now apply these results to the Thiessen polygons. We consider the region, $R$, to be the ploughzone area within the site boundary that was then sampled by means of ploughzone samples. Each of the constructed Thiessen polygons determines a subregion, $S$, of the region, $R$. A quadrat, $Q$, corresponds to a ploughzone sample and the quadrat area to the surface area equivalent for the 400-l ploughzone sample used to construct each Thiessen polygon. The number of flakes found in a ploughzone sample is the number, $n$, of artefacts for a quadrat.

The assumption that artefacts are randomly distributed over a subregion corresponds to the assumption that artefact density over a Thiessen polygon is constant and the latter assumption is used by the SYSTAT program to construct the polygons. The assumption that the random variables, $X_{i}$, are independent translates into the assumption that each

*Department of Anthropology, University of California, Los Angeles CA 90095, USA. 
ploughzone sample is randomly located within its associated Thiessen polygon. This assumption is not strictly valid as the polygon is determined by both the relative location and artefact densities (since ploughzone samples were spatially more dense in regions of greater artefact density) of the ploughzone samples. However, the sampling strategy for the location of the ploughzone samples tends to minimize any spatial autocorrelation effects. Lack of independence would introduce a covariance term in the computation of $\sigma_{x}{ }^{2}$. The sign of the covariance terms would be positive if there is (positive) spatial autocorrelation, hence the existence of spatial autocorrelation would tend to make the computed confidence intervals conservative. Thus the computed CIs given in TABLE 3 should be treated as minimum, estimated CIs. In TABLE 3 , the CIs obtained from Equation (6) with $\alpha=0 \cdot 05$, are given for each of the several sites used in the Thy Archaeological Project. 